\title{
ALTERNATIVES ANALYSIS FOR SELECTING ET \#3 SITE
}

\author{
L. B. Collard \\ L. L. Hamm
}

February 2012

Savannah River National Laboratory Savannah River Nuclear Solutions Savannah River Site Aiken, SC 29808 Prepared for the U.S. Department of Energy Under Contract Number DE-AC09-08SR22470

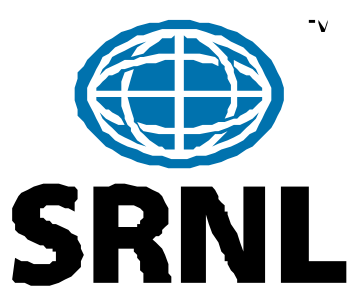




\section{DISCLAIMER}

This work was prepared under an agreement with and funded by the U.S. Government. Neither the U.S. Government or its employees, nor any of its contractors, subcontractors or their employees, makes any express or implied:

1. warranty or assumes any legal liability for the accuracy, completeness, or for the use or results of such use of any information, product, or process disclosed; or

2. representation that such use or results of such use would not infringe privately owned rights; or

3. endorsement or recommendation of any specifically identified commercial product, process, or service.

Any views and opinions of authors expressed in this work do not necessarily state or reflect those of the United States Government, or its contractors, or subcontractors.

Printed in the United States of America

Prepared For

U.S. Department of Energy 
Key Words:

Down-select

Quantitative

Qualitative

Option

Retention:

Permanent

\title{
ALTERNATIVES ANALYSIS FOR SELECTING ET \#3 SITE
}

\author{
L. B. Collard \\ L. L. Hamm
}

February 2012

Savannah River National Laboratory

Savannah River Nuclear Solutions

Savannah River Site

Aiken, SC 29808

Prepared for the U.S. Department of Energy Under

Contract Number DE-AC09-08SR22470

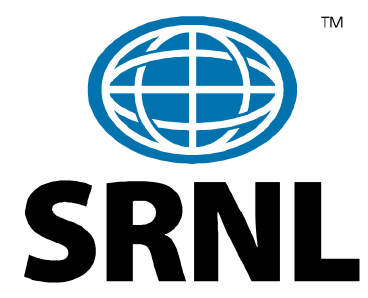




\section{REVIEWS AND APPROVALS}

\section{Authors:}

L.B. Collard, Radiological Performance Assessment

Date

L.L. Hamm, Engineering Modeling \& Simulation

Date

\section{Technical Reviewer:}

F.G. Smith, III, Engineering Modeling \& Simulation

Date

\section{Approvers:}

D.A. Crowley, Manager, Radiological Performance Assessment

Date

R.S. Aylward, Manager, Environmental Restoration Technology

Date

D.F. Sink, Facility/LLW Engineering

Date

F.L. Fox, Deputy Director, Solid Waste Management

Date 


\section{Table of Contents}

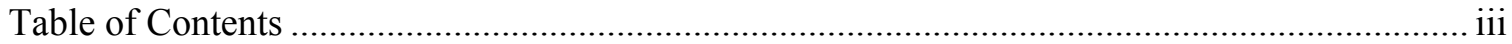

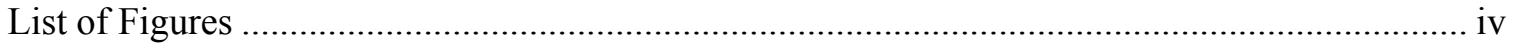

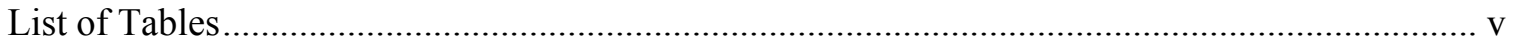

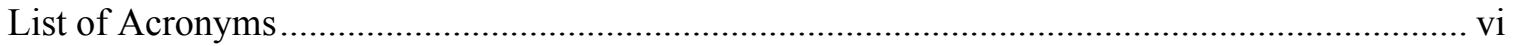

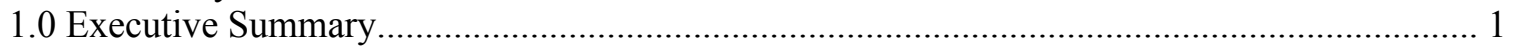

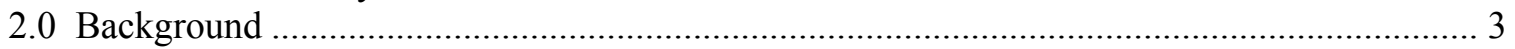

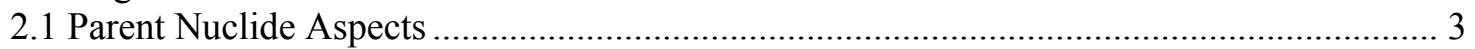

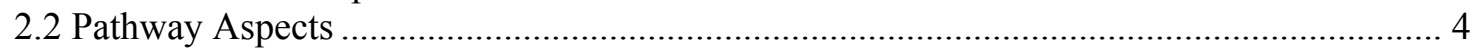

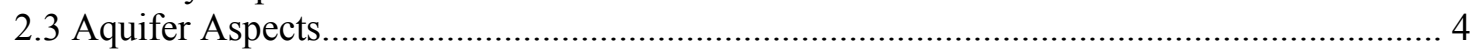

2.4 Disposal Unit Geometry Aspects ...................................................................... 5

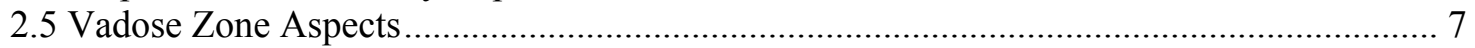

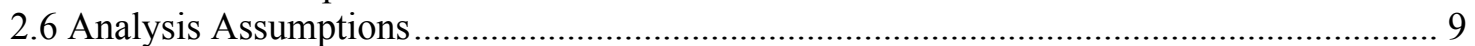

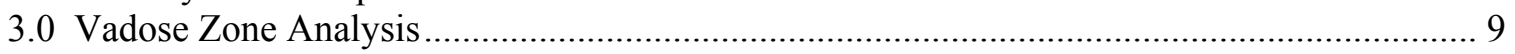

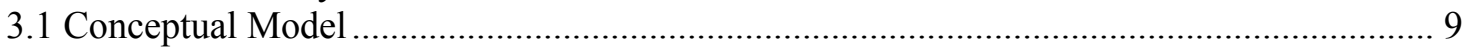

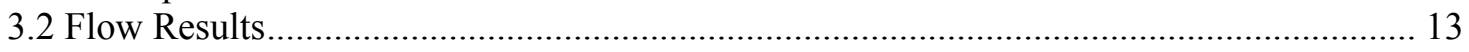

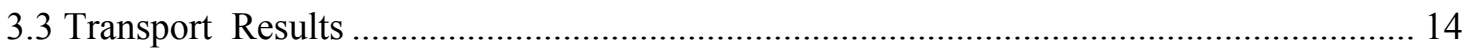

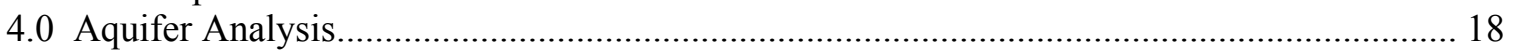

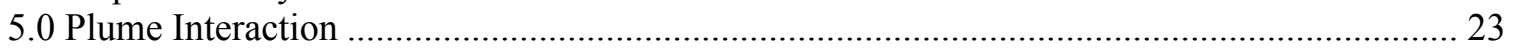

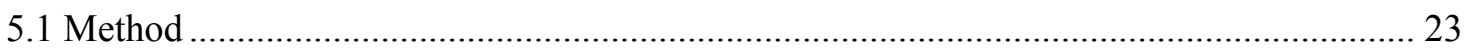

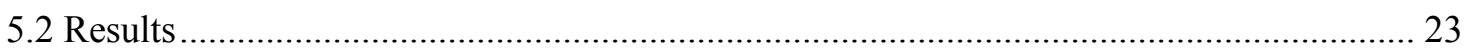

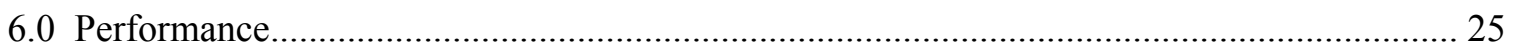

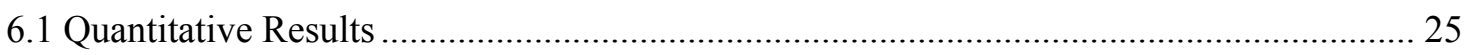

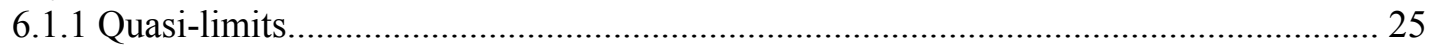

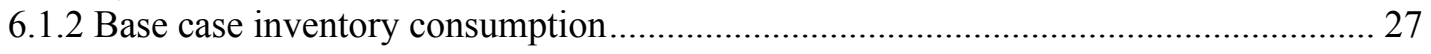

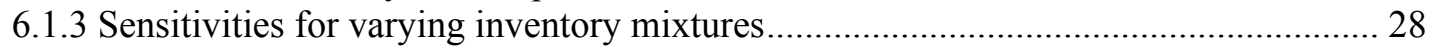

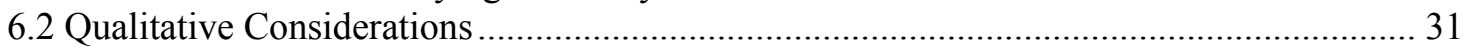

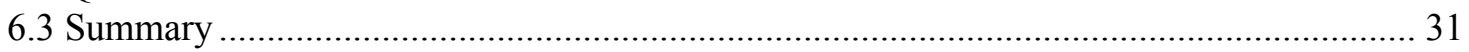

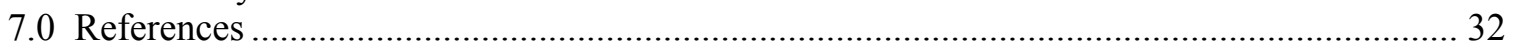

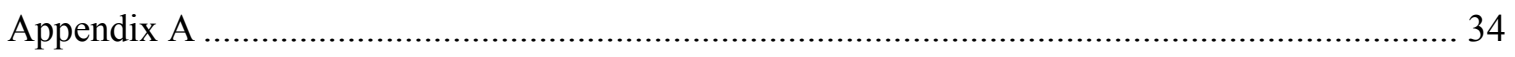




\section{List of Figures}

Figure 1-1 Aerial footprints of ET \#1, ET \#2, and each option and aquifer 3D streamtraces, which indicate the average radionuclide migration path emanating from each disposal unit of interest.

Figure 2-1 2D vadose zone cross-section for ET \#1, as modeled in the PA (2008)......................6

Figure 2-2 A comparison of the $2 \mathrm{D}$ vadose zone models for each of the four options................. 7

Figure 3-1 Cross-sectional view of each disposal unit within the vadose zone (to scale) where material properties are color coded for conditions before EIC......................................11

Figure 3-2 Cross-sectional view of each disposal unit within the vadose zone (to scale) where material properties are color coded for conditions after EIC........................................12

Figure 3-3 (a) Intact and (b) subsided example vadose zone flow profiles for two time periods for Option 3 with 5-year and 100-year time markers, respectively.

Figure 3-4 C-14 flux to the water table for Option 3 showing the intact, subsided, and blended results.

Figure 3-5 H-3 flux to the water table for Option 3 showing the intact, subsided, and blended results.

Figure 3-6 I-129 flux to the water table for Option 3 showing the intact, subsided, and blended results.

Figure 3-7 Np-237 flux to the water table for Option 3 showing the intact, subsided, and blended results (Np-237 - blue, U-233 - green, and Th-229 - red).

Figure 3-8 Sr-90 flux to the water table for Option 3 showing the intact, subsided, and blended results.

Figure 3-9 Tc-99 flux to the water table for Option 3 showing the intact, subsided, and blended results.

Figure 3-10 I-129 flux to the water table for each disposal unit under the intact (Case01_off) condition.

Figure 4-1 I-129 aquifer concentration profiles for Options 1, 3, and 4 (Case01_off condition) near their times of peak maximum well concentrations.

Figure 4-2 I-129 aquifer concentration profiles for Option 2 and ET \#1 (Case01_off condition) near their times of peak maximum well concentrations.

Figure 4-3 Maximum well concentrations vs. time, incorporating the plume interaction factor, for C-14 showing the intact (Case01_off) and 10\% blended (Case01n11_off) results. ..20

Figure 4-4 Maximum well concentrations vs. time, incorporating the plume interaction factor, for H-3 showing the intact (Case01_off) and 10\% blended (Case01n11_off) results.....20

Figure 4-5 Maximum well concentrations vs. time, incorporating the plume interaction factor, for I-129 showing the intact (Case01_off) and 10\% blended (Case01n11_off) results...21

Figure 4-6 Maximum well concentrations vs. time, incorporating the plume interaction factor, for Np-237 showing the intact (Case01_off) and 10\% blended (Case $01 n 11$ off) results.

Figure 4-7 Maximum well concentrations vs. time, incorporating the plume interaction factor, for Sr-90 showing the intact (Case01_off) and 10\% blended (Case01n11_off) results. .22

Figure 4-8 Maximum well concentrations vs. time, incorporating the plume interaction factor, for Tc-99 showing the intact (Case01_off) and 10\% blended (Case01n11_off) results..22

Figure 5-1 Horizontal slice of aquifer model showing concentrations with only Option 4's

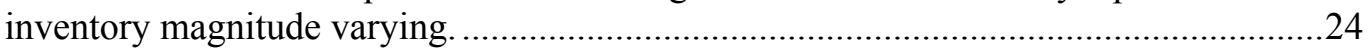

Figure 6-1 Estimated peak beta-gamma and all-pathways SOFs for selected time windows based on (a) ET \#1 inventory and (b) maximum historical inventories..........................27

Figure 6-2 Peak doses for sensitivity inventory sets: a) BG1, b) BG2, and c) AP.......................30 


\section{List of Tables}

Table 2-1 Historical nuclide inventories ( $\mathrm{Ci}$, as of 9/29/2011) for slit and engineered trenches...4

Table 2-2 Aerial footprint dimensions for each option and existing ET units.

Table 2-3 Average estimated travel distances and GW transport times within the aquifer for each unit from its centroid to its respective 100 -m boundary...................................5

Table 2-4 Vadose zone transport distances for each disposal unit. ..........................................6

Table 2-5 Key hydraulic properties employed in the vadose zone modeling...............................

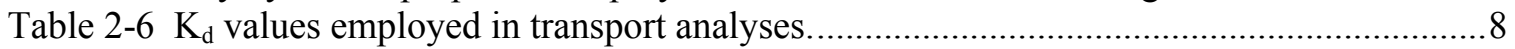

Table 2-7 Intact and subsided averaged surface infiltration rates for each option considered........8

Table 2-8 Timeline in terms of absolute and relative times employed..........................................

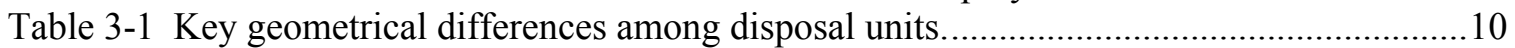

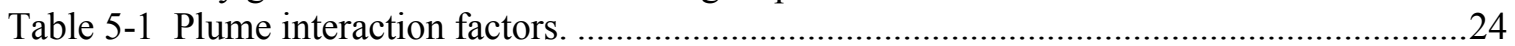

Table 6-1 Ingestion Dose Conversion Factors (mrem/yr per pCi/L) ......................................25

Table $6-2^{1}$ Groundwater quasi-limits (Ci) for beta-gamma and all-pathways................................26

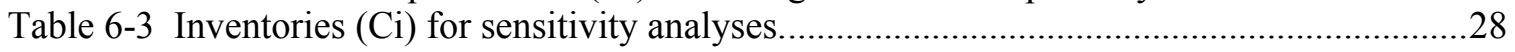

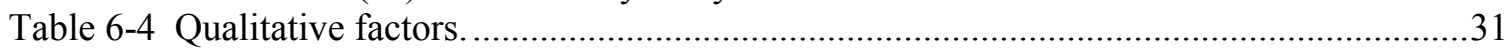




\section{List of Acronyms}

\begin{tabular}{|c|c|}
\hline AP & All-pathways \\
\hline BG & Beta-gamma \\
\hline BG1 & Beta-gamma (window 1) \\
\hline BG2 & Beta-gamma (window 2) \\
\hline CDP & Cellulose Degradation Products \\
\hline $\mathrm{Ci}$ & Curies \\
\hline DCF & Dose Conversion Factor (mrem/yr per pCi/L) \\
\hline $\mathrm{D}_{\mathrm{e}}$ & Saturated effective diffusion coefficient $\left(\mathrm{cm}^{2} / \mathrm{s}\right)$ \\
\hline DOE & Department of Energy \\
\hline ELLWF & E-Area Low Level Waste Facility \\
\hline EIC & End of institutional control \\
\hline EPP & End of performance period \\
\hline ET & Engineered Trench \\
\hline GSA & General Separations Area \\
\hline GW & Groundwater \\
\hline ILV & Intermediate Level Vault \\
\hline $\mathrm{K}_{\mathrm{d}}$ & Distribution Coefficient (ml/g) \\
\hline $\mathrm{K}_{\mathrm{h}}$ & Horizontal hydraulic conductivity $(\mathrm{cm} / \mathrm{s})$ \\
\hline $\mathrm{K}_{\mathrm{v}}$ & Vertical hydraulic conductivity $(\mathrm{cm} / \mathrm{s})$ \\
\hline LLRWDF & Low Level Radioactive Waste Disposal Facility \\
\hline LLW & Low Level Waste \\
\hline LVZ & Lower vadose zone \\
\hline MCL & Maximum Contaminant Level \\
\hline MWMF & Mixed Waste Management Facility \\
\hline OSC_NDC & E-Area Operational Soil Cover prior to Dynamic Compaction \\
\hline OSC_DC & E-Area Operational Soil Cover after Dynamic Compaction \\
\hline $\mathrm{PA}-$ & Performance Assessment \\
\hline PORFLOW & Porous flow (porous-media flow and transport FORTRAN code) \\
\hline SA & Special Analysis \\
\hline SEG & Scientific Ecology Group \\
\hline SIC & Start of institutional control \\
\hline SOF & Sum-of-Fractions \\
\hline SOP & Start of operations \\
\hline SRNL & Savannah River National Laboratory \\
\hline SRS & Savannah River Site \\
\hline ST & Slit Trench \\
\hline SW & Solid Waste \\
\hline TRU & Transuranic \\
\hline UDQ & Unreviewed Disposal Question \\
\hline UVZ & Upper vadose zone \\
\hline WT & Water table \\
\hline $2 \mathrm{D}$ & two dimensional (geometry) \\
\hline $3 \mathrm{D}$ & three dimensional (geometry) \\
\hline
\end{tabular}




\subsection{Executive Summary}

Engineered trenches (ETs) are considered to be a cost-effective method for disposing Low Level Waste (LLW). Based on waste forecasts from waste generators, the last engineered trench in operation (ET \#2) is anticipated to close in FY14, requiring development of a new ET. Solid Waste requested that SRNL develop an assessment report that reviews four disposal options for this new ET (ET \#3) and determine which option would provide the "best" Performance Assessment (PA) disposal limits for LLW (Appendix A). Those four options (see option footprint locations in Figure 1-1) are:

1. Disposal at grade on TRU Pads 7-13 where soil would be mounded over waste packages;

2. Excavation at a slightly modified SLIT \#13 location - near the Used Equipment Storage Area;

3. Excavation at a modified SLIT \#12 location - near the 643-26E Naval Reactor Component Disposal Area; and

4. Excavation east of TRU Pad \#26 that replaces northeast portions of four slit trench (ST) disposal units in the eastern set of STs.

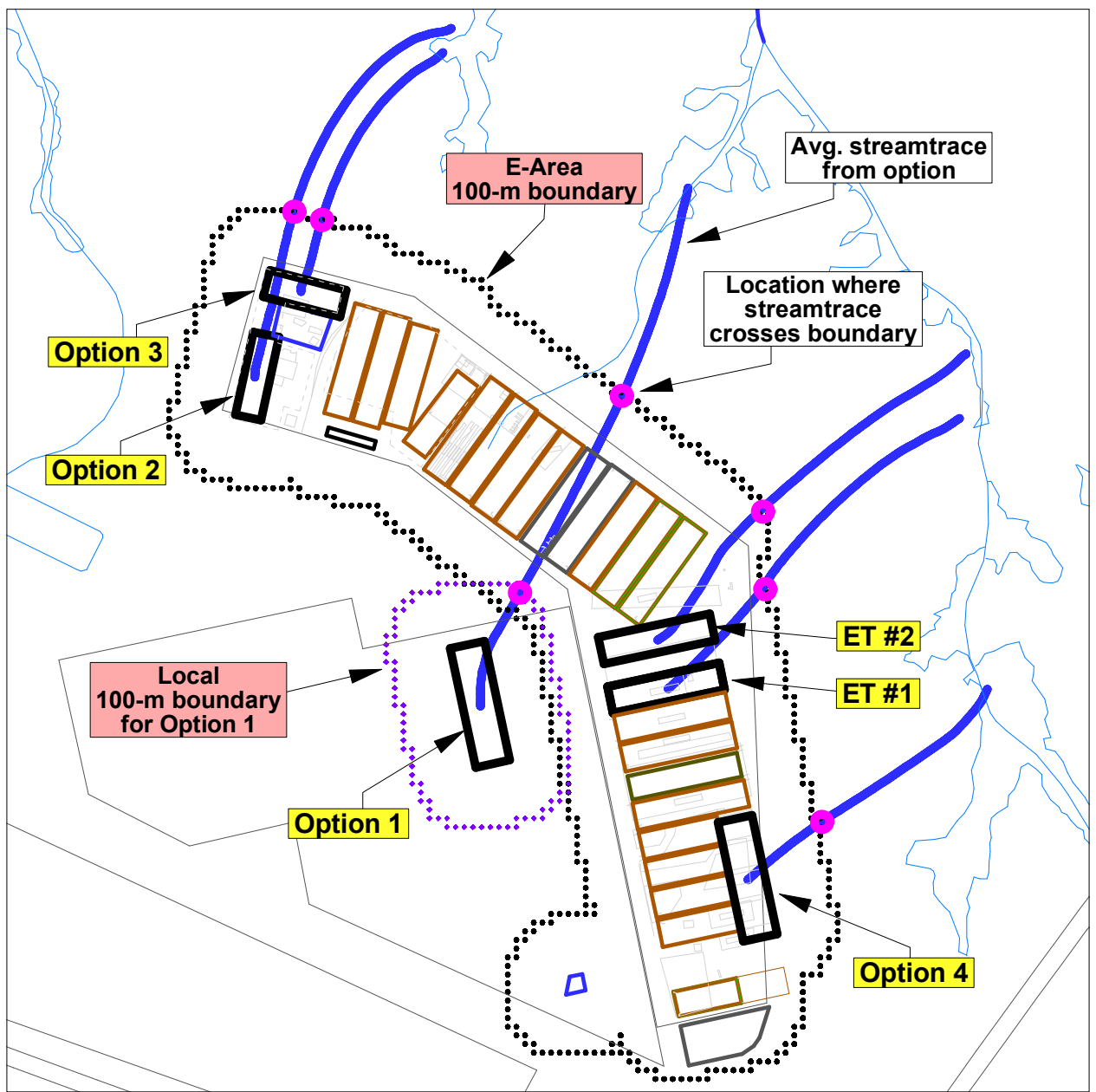

Figure 1-1 Aerial footprints of ET \#1, ET \#2, and each option and aquifer 3D streamtraces, which indicate the average radionuclide migration path emanating from each disposal unit of interest. 
The assessment consisted of both quantitative and qualitative analyses. The quantitative analysis captured key aspects that were readily quantifiable and had predictable impacts on limits and doses. A simplified modeling strategy stemming from current Special Analysis (SA) practices was employed. Both inventory capacity for a specific nuclide (a quasi-inventory limit) and overall performance for specified inventory mixtures (doses resulting from historical inventories) were considered. The qualitative analysis evaluated other key aspects based on engineering judgment in the form of "pros" and "cons."

Based on the quantitative analysis, the following conclusions were drawn:

- No definitively clear choice from all four options can be made when viewing just inventory capacities of a specific nuclide or overall performance with respect to historical inventory mixtures;

- Option 4 has the worst performance when viewing quasi-inventory limits (except for C14) or overall performance;

- Options 1, 2, and 3 perform consistently better than ET \#1 (which performs better than Option 4) when viewed on an overall performance basis (i.e., results based on a consistent analysis approach);

- Option 1 on average performs better than Options 2 and 3; and

- Relative performances among Options 1,2, and 3 are marginally dependent on the assumed inventory mixture (i.e., if the anticipated inventory is outside of the historical trends then an optimum choice among these three options may be possible).

Based on qualitative considerations the following conclusions were drawn:

- Option 1 results in increased potential costs associated with developing an SA (issues with concrete pads, point of assessment, cap design, etc. will require additional efforts);

- Option 1 construction and operations may require regulatory approvals (e.g., due to its proximity to the MWMF and LLRWDF caps); however,

- Option 1 does provide increased inventory capacity to E-Area without reducing future ST space as the other options do.

In combining the above quantitative analysis results with the qualitative considerations, the following observations were made:

- Option 4 is the most undesirable due to its measurably poorer inventory performance;

- Option 1 appears less desirable than Options 2 and 3 due to potentially significant regulatory and SA risks; and

- Options 2 and 3 are quantitatively and qualitatively the most desirable and appear to be equally suitable locations.

Details of the quantitative analysis results and the qualitative considerations mentioned above are addressed within the main body of this report. 


\subsection{Background}

Two Engineered Trench (ET) disposal units currently exist within the E-Area disposal facility (i.e., ET \#1 and ET \#2). ET \#1 is nearly closed and ET \#2 is currently being filled. Based on current Performance Assessment (PA) disposal limits (PA, 2008), ET disposal units for handling Low Level Waste (LLW) are considered to be a cost-effective method for disposal of containerized LLW. Solid Waste estimates closure of ET \#2 in FY14 based on LLW disposed to date and waste forecasts from the waste generators. Therefore, it is desirable to develop an additional ET disposal unit (i.e., ET \#3).

Solid Waste identified four candidate locations (see Appendix A) for the proposed ET \#3 and requested SRNL to develop an assessment report that: (1) reviews each disposal option (i.e., qualitative evaluation) and (2) determines which option would provide the "best" PA disposal limits for LLW (i.e., quantitative evaluation). The "best" limits can be viewed from both individual parent nuclide inventory capacities as well as expected performance resulting from composite inventories.

In order to assess the quantitative performance of the proposed options, from a radioactive inventory perspective, the following items were considered (with some of their impacts shown in parentheses):

- Only six dominant parent nuclides;

- Only beta-gamma pathway and groundwater (GW) all-pathways;

- Aquifer aspects based on the location of each disposal unit (travel distance and time, plume dispersion);

- Geometrical width of disposal unit (subsided infiltration rates and waste concentration, which is also affected by the length);

- Vadose zone stratigraphy (e.g., thicknesses of clay and sand below waste zone); and

- Analysis assumptions (e.g., all waste inventory buried at start of operations).

Each of these topics is discussed in greater detail in the sections below.

\subsection{Parent Nuclide Aspects}

Typically only a few waste nuclides dominate the GW dose at the $100-\mathrm{m}$ boundaries. The process to choose the key parents involved:

- Limiting the total to six parent nuclides;

- Having at least one mobile and one less mobile nuclide;

- Having at least one nuclide that is sensitive to subsidence; and

- Considering dominant contributors to the overall SOFs for ET \#1 and ET \#2.

This process resulted in choosing C-14, H-3, I-129, Np-237, Sr-90, and Tc-99. These six nuclides were also chosen for the SW annual report (see Swingle et al., 2012).

For assistance in determining disposal unit performance for a specified inventory, two inventory sets were considered: one set based on ET \#1's inventories for these six nuclides and the other set based on maximum inventory values for disposal units observed historically. The second set addressing inventory sensitivities was determined from historical inventories taken from all slit and engineered trenches. Table 2-1 contains the historical inventories (as of 9/29/2011) considered where the overall maximum values for each nuclide are highlighted. The maximum historical inventory for any parent was the greatest inventory disposed in any Engineered Trench or Slit Trench in the E-Area. One exception was made for H-3 in the SEG boxes which exceeded their original inventory limits. Hence, for ST4, its H-3 inventory was reduced from 8.6 Ci to 0.62 $\mathrm{Ci}$ (subtracting the H-3 inventory in the SEG boxes). "MAX" refers to the maximum value, 
"AVG" refers to the average value, "RMS" refers to the root-mean-square (a measure of variation about the average value), and "\%RMS/AVG" refers to the percent value of the quotient RMS/AVG (ex. I-129 nominally varied $71 \%$ about its average value). These values were computed for each nuclide over the twelve disposal units listed.

\subsection{Pathway Aspects}

Inventory limits for the groundwater pathways typically are much lower than other pathways (e.g., inadvertent intruder or air). Within the groundwater pathways, the beta-gamma and all-pathways typically are most important; hence results are only reported for their analyses.

Table 2-1 Historical nuclide inventories ( $\mathrm{Ci}$, as of 9/29/2011) for slit and engineered trenches.

\begin{tabular}{|c|c|c|c|c|c|c|}
\hline Disposal Unit & C-14 & $\mathrm{H}-3$ & I-129 & Np-237 & Sr-90 & Tc-99 \\
\hline \multirow{3}{*}{$\begin{array}{l}\text { SLIT1 } \\
\text { SLIT2 } \\
\text { SLIT3 }\end{array}$} & $8.9 \mathrm{E}-03$ & $8.5 \mathrm{E}-01$ & $2.0 \mathrm{E}-05$ & $1.2 \mathrm{E}-03$ & $3.2 \mathrm{E}+00$ & $5.3 \mathrm{E}-03$ \\
\hline & $4.6 \mathrm{E}-02$ & $1.1 \mathrm{E}+00$ & $2.0 \mathrm{E}-05$ & $2.1 \mathrm{E}-03$ & $4.7 \mathrm{E}+00$ & $2.0 \mathrm{E}-02$ \\
\hline & 1.9E-02 & $8.5 \mathrm{E}-01$ & $4.5 \mathrm{E}-05$ & $1.9 \mathrm{E}-02$ & $3.1 \mathrm{E}+01$ & $3.9 \mathrm{E}-02$ \\
\hline \multirow{2}{*}{$\begin{array}{l}\text { SLIT4 } \\
\text { SLIT5 }\end{array}$} & 3.7E-02 & $6.2 \mathrm{E}-01$ & $3.5 \mathrm{E}-05$ & 7.6E-03 & $1.7 \mathrm{E}+01$ & $5.1 \mathrm{E}-02$ \\
\hline & 3.6E-02 & 4.0E-01 & $5.7 \mathrm{E}-05$ & $5.6 \mathrm{E}-03$ & $4.1 \mathrm{E}+01$ & $4.5 \mathrm{E}-02$ \\
\hline SLIT6 & $7.9 \mathrm{E}-03$ & $2.0 \mathrm{E}-01$ & $7.2 \mathrm{E}-05$ & 4.0E-03 & $2.7 E+01$ & $2.1 \mathrm{E}-02$ \\
\hline \multirow{2}{*}{ SLIT7 } & 2.3E-02 & 4.3E-01 & 3.0E-05 & 4.7E-03 & $5.9 \mathrm{E}+00$ & $8.3 \mathrm{E}-03$ \\
\hline & $1.8 \mathrm{E}-02$ & $2.7 \mathrm{E}-01$ & $9.0 \mathrm{E}-05$ & 4.4E-04 & $3.7 \mathrm{E}+00$ & $4.9 \mathrm{E}-03$ \\
\hline $\begin{array}{l}\text { SLIT8 } \\
\text { SLIT9 }\end{array}$ & $8.8 \mathrm{E}-04$ & $9.6 \mathrm{E}-02$ & $4.9 \mathrm{E}-06$ & $2.4 \mathrm{E}-03$ & $3.1 \mathrm{E}+00$ & $1.1 \mathrm{E}-02$ \\
\hline \multirow{3}{*}{$\begin{array}{l}\text { SLIT14 } \\
\text { ET \#1 } \\
\text { ET \#2 }\end{array}$} & $1.2 \mathrm{E}-03$ & $2.3 \mathrm{E}-02$ & $4.0 \mathrm{E}-07$ & $1.5 \mathrm{E}-03$ & $1.4 \mathrm{E}+00$ & $9.2 \mathrm{E}-04$ \\
\hline & 1.3E-01 & $2.2 \mathrm{E}+00$ & $7.2 \mathrm{E}-05$ & $7.7 \mathrm{E}-03$ & $2.5 \mathrm{E}+01$ & $3.9 \mathrm{E}-02$ \\
\hline & $3.1 \mathrm{E}-02$ & $3.4 \mathrm{E}-01$ & $1.8 \mathrm{E}-05$ & $2.4 \mathrm{E}-02$ & $4.8 \mathrm{E}+01$ & $3.6 \mathrm{E}-02$ \\
\hline \multirow{3}{*}{$\begin{array}{l}\text { MAX } \\
\text { AVG } \\
\text { RMS }\end{array}$} & 1.3E-01 & $2.2 \mathrm{E}+00$ & $9.0 \mathrm{E}-05$ & $2.4 \mathrm{E}-02$ & $4.8 \mathrm{E}+01$ & $5.1 \mathrm{E}-02$ \\
\hline & $3.0 \mathrm{E}-02$ & $6.1 \mathrm{E}-01$ & $3.9 \mathrm{E}-05$ & $6.7 \mathrm{E}-03$ & $1.8 \mathrm{E}+01$ & $2.3 \mathrm{E}-02$ \\
\hline & $3.3 \mathrm{E}-02$ & $5.7 \mathrm{E}-01$ & $2.7 \mathrm{E}-05$ & $7.1 \mathrm{E}-03$ & $1.6 \mathrm{E}+01$ & $1.7 \mathrm{E}-02$ \\
\hline$\%$ RMS/AVG & 111 & 93 & 71 & 106 & 89 & 72 \\
\hline
\end{tabular}

\subsection{Aquifer Aspects}

For an overall aquifer groundwater (GW) flow perspective, the general migration path taken for each option is plotted in Figure 1-1 (from Jordan, 2011). 3D streamtraces are shown as thick blue curves emanating from the water table surface at each option's footprint centroid. These streamtraces were computed from the "best estimate" GSA aquifer flow model. Magenta circles indicate where these streamtraces cross their appropriate 100-m boundary. Small, solid black circles represent the E-Area 100-m boundary, while small, solid purple circles represent a "local" $100-\mathrm{m}$ boundary around Option 1 . Option 1 required two $100-\mathrm{m}$ boundaries because of differing plume interaction factors. Option 1's peak well concentrations typically occur immediately outside its local 100-m boundary where no plume interaction occurs with E-Area waste disposals (this area is also outside the E-Area 100-m boundary). However, further down-gradient, Option 1 's plume does interact with E-Area waste disposal plumes, thus its peak well concentration beyond the E-Area boundary was also investigated where a plume interaction factor greater than one was employed.

The aerial dimensions of the four options, along with those for the existing ET units, are provided in Table 2-2. In the PA (2008) the ET \#2 geometry was employed for both units. In Table 2-3 estimated travel lengths and pore water travel times are provided. These values represent average aquifer transport from each option to its appropriate 100-m boundary. As Table 2-3 indicates, wide ranges of travel distances and times exist which can play an important role in the overall performance of a given parent nuclide. 
Table 2-2 Aerial footprint dimensions for each option and existing ET units.

\begin{tabular}{|c|c|c|c|}
\hline \multirow{2}{*}{ Option } & $\begin{array}{c}\text { Length } \\
\text { (ft) }\end{array}$ & $\begin{array}{c}\text { Width } \\
\text { (ft) }\end{array}$ & $\begin{array}{c}\text { Area } \\
\left(\mathbf{f t}^{2}\right) \mathbf{x 1 0 0 0}\end{array}$ \\
\hline \hline \multirow{2}{*}{$\begin{array}{c}\text { ET \#1 } \\
\text { ET \#2 }\end{array}$} & 650 & 150 (modeled as 160) & 98 \\
\cline { 2 - 4 } & 656 & 160 & 105 \\
\cline { 2 - 4 } $\mathbf{2}$ & 700 & 200 & 140 \\
\cline { 2 - 4 } $\mathbf{3}$ & 489 & 150 & 73 \\
\cline { 2 - 4 } & 456 & 157 & 72 \\
\cline { 2 - 4 } & 700 & 200 & 140 \\
\hline
\end{tabular}

1 - ET \#1 and ET \#2 were modeled using a generic 160 foot wide ET unit in the PA.

Table 2-3 Average estimated travel distances and GW transport times within the aquifer for each unit from its centroid to its respective 100-m boundary.

\begin{tabular}{|c|c|c|c|}
\hline Option & $\begin{array}{l}\text { 100-m Boundary } \\
\text { (id) }\end{array}$ & $\begin{array}{c}\text { Travel Distance } \\
\text { (ft) }\end{array}$ & $\begin{array}{c}\text { Travel Time } \\
\text { (yr) }\end{array}$ \\
\hline ET \#1 & E-Area & 800 & $\begin{array}{ll}10.0 \\
\end{array}$ \\
\hline ET \#2 & E-Area & 940 & 9.6 \\
\hline 1 & Local & 700 & 10.6 \\
\hline 1 & E-Area & 1960 & 17.4 \\
\hline 2 & E-Area & 990 & 5.7 \\
\hline 3 & E-Area & 450 & 1.9 \\
\hline 4 & E-Area & 480 & 4.3 \\
\hline
\end{tabular}

\subsection{Disposal Unit Geometry Aspects}

To make a consistent comparison among all four options, the same analysis methodology was employed for each option. To make a relative comparison to ET \#1, the same analysis methodology was applied to ET \#1 (e.g., the same $\mathrm{K}_{\mathrm{d}}$ 's were used), but the uniqueness of ET \#1's location, aerial footprint and vadose zone stratigraphy were modeled.

For the down-select process, five different vadose zone 2D PORFLOW models were created (as shown in Figures 2-1 and 2-2):

- Option 1 (outside E-Area);

- Option 2 (West Slit Trench region);

- Option 3 (West Slit Trench region);

- Option 4 (East Slit Trench region); and

- $\quad$ ET \#1 (between East and Center Slit Trench regions).

Option 1 is unique in that the waste zone results from stacking waste containers on top of the existing ground surface (existing discrete concrete pads were assumed to have been removed for this analysis). At the other four locations, 16 feet of excavation was assumed prior to placement of waste containers. This report followed the PA approach, where the ET vadose zone model in the PA employed a similar 16-foot excavation with excavated soil being placed alongside the excavation, thus raising the adjacent final ground surface by four feet. Excavated material was also used to provide the four feet of clean soil above the disposed waste. PA Section 1.3.2 states that ET \#1 "varies in depth from 16 to 25 feet while ET \#2 "varies in depth from 14 to 23 feet." The portions of ET \#2 that were only 14 feet deep actually caused some of the waste to extend above the original ground surface.

In order to create more realistic $2 \mathrm{D}$ vadose zone models for each option, estimates of the average depth to the water table and depth to the lower vadose zone (LVZ, where the upper clay zone terminates) were required (i.e., depths measured from ground surface). The depths to the water table were extracted from prior water table surfaces provided by Hiergesell (2011). The depths to 
the lower vadose zone were estimated by Millings (2011). Table 2-4 lists these key values, along with the values employed for ET \#1 (note, in the PA, 2008, no crusher run was modeled).

Table 2-4 Vadose zone transport distances for each disposal unit.

\begin{tabular}{|c|c|c|c|c|}
\hline Option & $\begin{array}{c}\text { Crusher Run } \\
\text { Depth (ft) }\end{array}$ & $\begin{array}{c}\text { Clay Distance } \\
\text { (ft) }\end{array}$ & $\begin{array}{c}\text { Sand } \\
\text { Distance (ft) }\end{array}$ & $\begin{array}{c}\text { Total } \\
\text { Distance (ft) }\end{array}$ \\
\hline \hline $\mathbf{1}$ & 1 & 22 & 28 & 51 \\
\cline { 2 - 5 } & 1 & 0 & 45 & 46 \\
$\mathbf{3}$ & 1 & 0 & 45 & 46 \\
\cline { 2 - 5 } & 1 & 6 & 20 & 27 \\
ET \#1 & 1 & 0 & 34 & 35 \\
\cline { 2 - 5 }
\end{tabular}

Figure 2-1 shows the material property zones (in different colors) chosen for the vadose zone models, along with key dimensions. These material zones are consistent across all five disposal units. Waste containers were only placed within the center section of the trench (i.e., the side regions contained only backfill material). Potential subsidence was limited to the outer ten feet of the waste zone (on the right-hand side).

Figure 2-2 shows a comparison among the 2D vadose zone models for all four options. All these diagrams are to scale where the relative differences in sand and clay transport distances beneath the waste zone can be seen directly. The location of the original ground level is also highlighted.

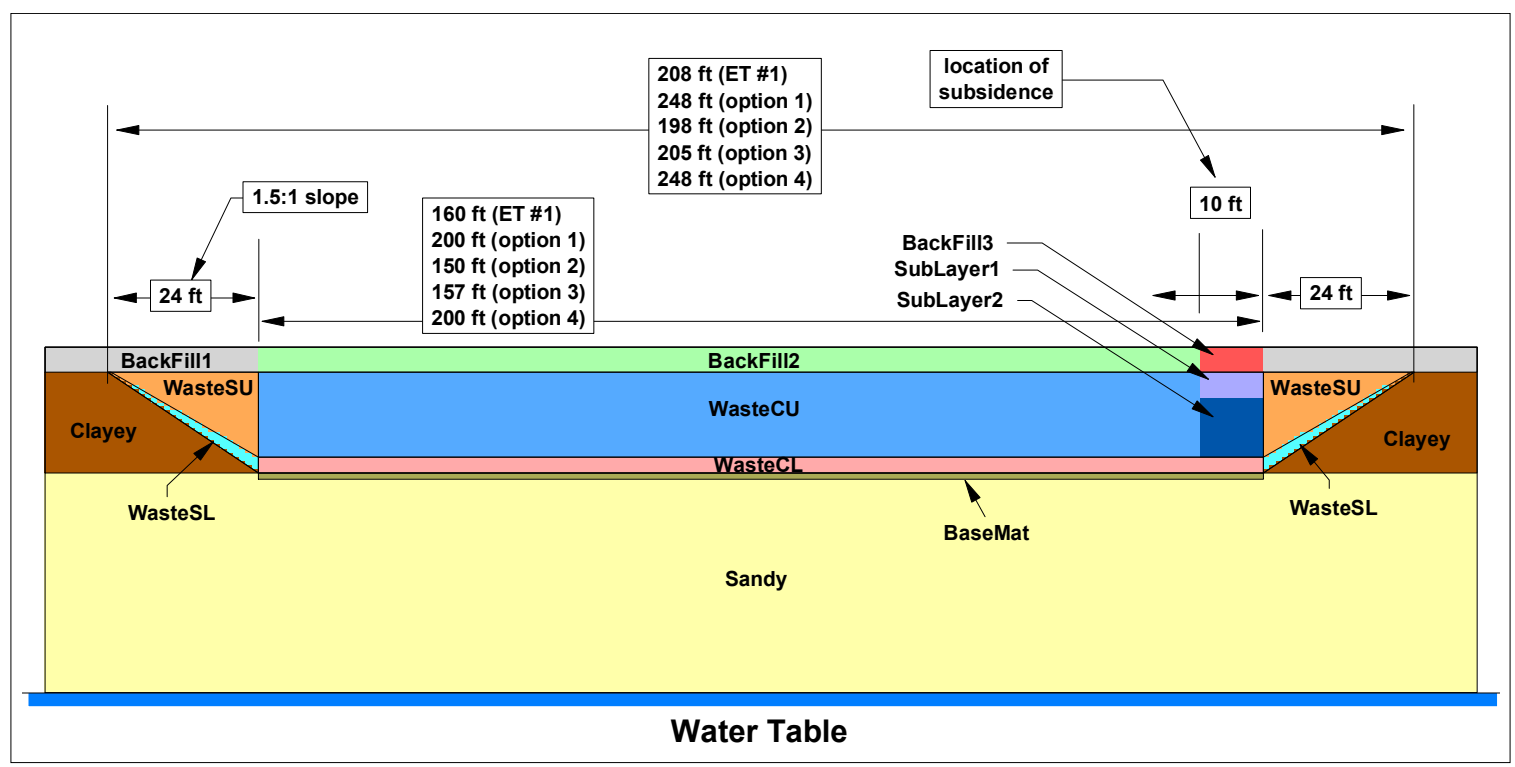

Figure 2-1 2D vadose zone cross-section for ET \#1, as modeled in the PA (2008). 


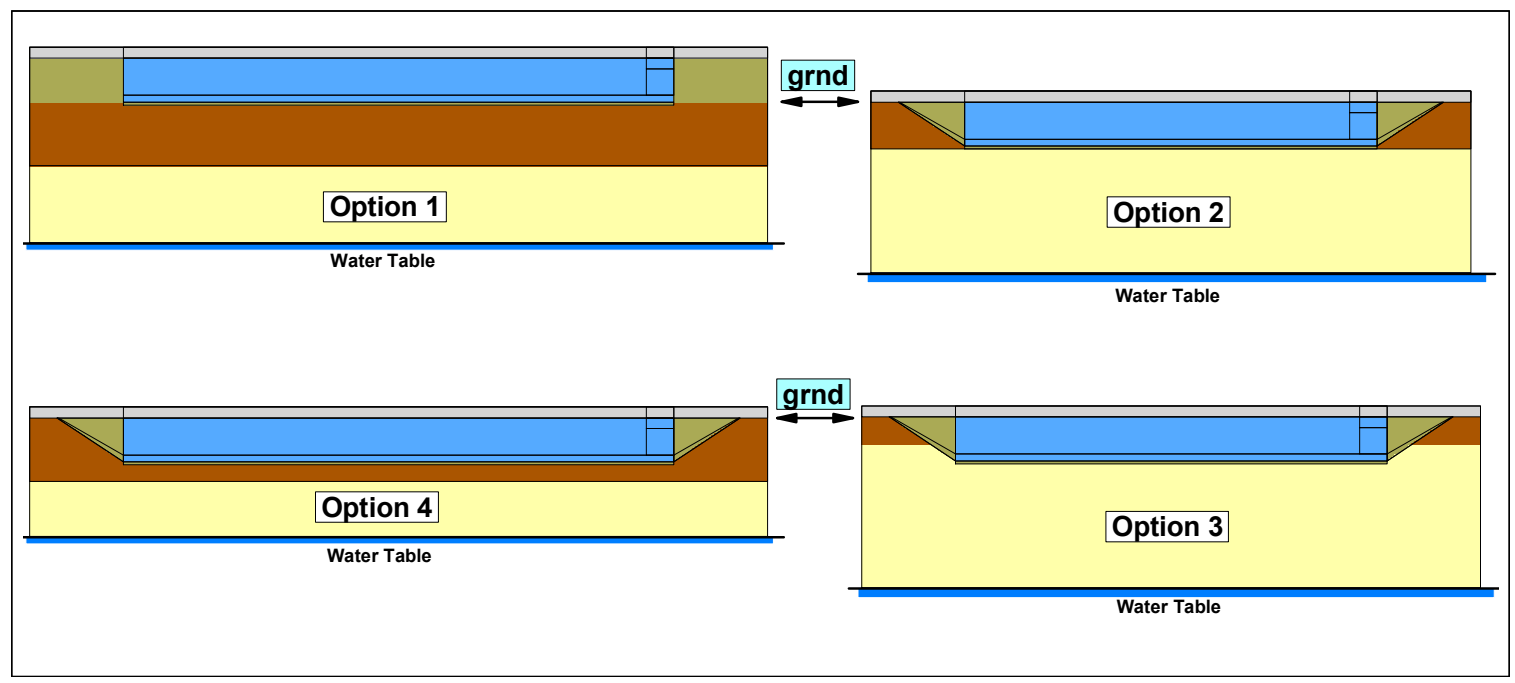

Figure 2-2 A comparison of the 2D vadose zone models for each of the four options.

\subsection{Vadose Zone Aspects}

The key hydraulic properties chosen are listed in Table 2-5 and represent the ten different materials depicted in Figures 2-1 and 2-2.

As Table 2-4 indicates, a wide range of sand versus clay transport distances exist for the various disposal units. For the limited set of nuclides considered their sand and clay $\mathrm{K}_{\mathrm{d}}$ values are listed in Table 2-6. Only $\mathrm{K}_{\mathrm{d}}$ 's for no cellulose degradation products (CDP) being present were considered and were taken from Kaplan (2010).

Table 2-5 Key hydraulic properties employed in the vadose zone modeling.

\begin{tabular}{|c|c|c|c|c|c|c|c|}
\hline Material & \begin{tabular}{|c} 
Saturated \\
Horizontal \\
Hydraulic \\
Conductivity, \\
Kh $(\mathrm{cm} / \mathrm{s})$
\end{tabular} & \begin{tabular}{|c} 
Saturated \\
Vertical \\
Hydraulic \\
Conductivity, \\
Kv (cm/s)
\end{tabular} & $\mathrm{Kh} / \mathrm{Kv}$ & $\begin{array}{c}\text { Water } \\
\text { Retention } \\
\text { Curves } \\
\end{array}$ & $\begin{array}{c}\text { Total } \\
\text { Porosity } \\
(\%)\end{array}$ & $\begin{array}{l}\text { Particle } \\
\text { Density } \\
\left(\mathrm{g} / \mathrm{cm}^{3}\right)\end{array}$ & $\begin{array}{l}\text { Saturated } \\
\text { Effective } \\
\text { Diffusion } \\
\text { Coefficient, } \\
\text { De }\left(\mathrm{cm}^{2} / \mathrm{s}\right) \\
\end{array}$ \\
\hline Upper Vadose Zone & 6.2E-05 & 8.7E-06 & 7.1 & same & 39 & 2.705 & $5.3 \mathrm{E}-06$ \\
\hline Lower Vadose Zone & 3.3E-04 & 9.1E-05 & 3.6 & same & 39 & 2.656 & $5.3 \mathrm{E}-06$ \\
\hline $\begin{array}{l}\text { E-Area Operational Soil Cover } \\
\text { Prior to Dynamic Compaction }\end{array}$ & $1.2 \mathrm{E}-04$ & 1.2E-04 & 1.0 & same & 46 & 2.650 & $5.3 \mathrm{E}-06$ \\
\hline $\begin{array}{c}\text { E-Area Operational Soil Cover } \\
\text { after Dynamic Compaction }\end{array}$ & $1.4 \mathrm{E}-05$ & 1.4E-05 & 1.0 & same & 27.46 & 2.650 & 4.0E-06 \\
\hline Control Compacted Backfill & 7.6E-05 & 4.1E-05 & 1.9 & same & 35 & 2.631 & $5.3 \mathrm{E}-06$ \\
\hline Sand $(<25 \%$ Mud $)$ & 5.0E-04 & $2.8 \mathrm{E}-04$ & 1.8 & same & 38 & 2.661 & 8.0E-06 \\
\hline $\begin{array}{l}\text { E-Area Containerized Waste } \\
\text { Prior to Dynamic Compaction }\end{array}$ & 1.2E-04 & 1.2E-04 & 1.0 & OSC_NDC & 89.43 & 2.650 & $5.3 \mathrm{E}-06$ \\
\hline $\begin{array}{l}\text { E-Area Containerized Waste } \\
\text { after Dynamic Compaction }\end{array}$ & 1.4E-05 & 1.4E-05 & 1.0 & OSC_DC & 31.70 & 2.650 & 4.0E-06 \\
\hline Composite Subsided Layer 1 & $7.5 \mathrm{E}-04$ & $7.5 \mathrm{E}-04$ & 1.0 & Sand & 41 & 2.650 & 8.0E-06 \\
\hline Composite Subsided Layer 2 & $1.1 \mathrm{E}-05$ & $1.1 \mathrm{E}-05$ & 1.0 & OSC_DC & 27.46 & 2.650 & $4.0 \mathrm{E}-06$ \\
\hline
\end{tabular}


Table 2-6 $\mathrm{K}_{\mathrm{d}}$ values employed in transport analyses.

\begin{tabular}{|c|c|c|}
\hline \multirow{2}{*}{ Element } & $\begin{array}{c}\text { Sand } \mathbf{K}_{\mathbf{d}} \\
(\mathbf{m l} / \mathbf{g})\end{array}$ & $\begin{array}{c}\text { Clay } \mathbf{K}_{\mathbf{d}} \\
(\mathbf{m l} / \mathbf{g})\end{array}$ \\
\hline \hline $\mathbf{C}$ & $10(1)$ & $400(30)$ \\
\cline { 2 - 3 } & 0 & 0 \\
\cline { 2 - 3 } $\mathbf{N p}$ & 0.3 & 0.9 \\
\cline { 2 - 3 } $\mathbf{S r}$ & 3 & 9 \\
\cline { 2 - 3 } $\mathbf{T c}$ & 5 & 17 \\
\cline { 2 - 3 } & 0.6 & 1.8 \\
\cline { 2 - 3 } Th (Np-237 daughter) & 900 & 2000 \\
\cline { 2 - 3 } U (Np-237 daughter) & 200 & 300 \\
\hline
\end{tabular}

Database $\mathrm{K}_{\mathrm{d}}$ values (Kaplan 2010) for $\mathrm{C}$ are 10 and $400 \mathrm{ml} / \mathrm{g}$ for sand and clay, respectively. However, about six months of contact time is needed to achieve equilibrium (Roberts and Kaplan 2008), and groundwater moves much faster so local equilibrium would never be achieved. Therefore $\mathrm{K}_{\mathrm{d}}$ values after one or two days of contact time were selected as effective modeling values (as shown in Table 2-6), i.e., $1 \mathrm{ml} / \mathrm{g}$ and $30 \mathrm{ml} / \mathrm{g}$. These values were also used previously in Collard and Hamm (2011).

Surface infiltration rates were estimated by Phifer (2011) for the intact case and the subsided case for each option. Phifer (2011) values were interpolated at 24 points in time to provide vadose zone flow profiles over the entire performance period. The subsided values are geometrydependent and thus varied for each option as listed in Table 2-7 (because Options 1 and 4 had the widest cross-section, they had the greatest run-on in the subsided region and the greatest infiltration rates for the subsidence case). Time-averaged values are listed in Table 2-7 for each of the 24 selected time periods.

Table 2-7 Intact and subsided averaged surface infiltration rates for each option considered.

\begin{tabular}{|c|c|c|c|c|c|c|c|c|}
\hline & & & Intact Case & \multicolumn{3}{|c|}{ Subsidence Case } & Intact & Subsidence \\
\hline $\begin{array}{l}\text { Time } \\
\text { index }\end{array}$ & Start Year ${ }^{1}$ & $\begin{array}{l}\text { End } \\
\text { Year }\end{array}$ & $\begin{array}{l}\text { All Options } \\
\text { (in/yr) }\end{array}$ & \begin{tabular}{|c|} 
Options $1 \& 4$ \\
(in/yr)
\end{tabular} & $\begin{array}{c}\text { Option } 2 \\
\text { (in/yr) }\end{array}$ & $\begin{array}{c}\text { Option } 3 \\
\text { (in/yr) }\end{array}$ & $\begin{array}{c}\text { PA } \\
\text { (in/yr) }\end{array}$ & $\begin{array}{c}\text { PA } \\
\text { (in/yr) } \\
\end{array}$ \\
\hline$\overline{11}$ & -125(SOP) & -100 & 15.75 & - & - & 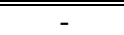 & - & - \\
\hline 2 & -100 (SIC) & 0 & 0.360 & - & - & - & - & - \\
\hline 3 & $0(\mathrm{EIC})$ & 50 & 0.00316 & 166.3 & 126.9 & 132.3 & 0.102 & 32.1 \\
\hline 4 & 50 & 100 & 0.00772 & 166.3 & 126.8 & 132.2 & 0.179 & 32.0 \\
\hline 5 & 100 & 150 & 0.0575 & 165.9 & 126.5 & 131.9 & 0.398 & 31.7 \\
\hline 6 & 150 & 200 & 0.157 & 164.9 & 125.9 & 131.2 & 0.687 & 31.4 \\
\hline 7 & 200 & 250 & 0.254 & 164.1 & 125.3 & 130.5 & 0.976 & 31.0 \\
\hline 8 & 250 & 290 & 0.335 & 163.4 & 124.7 & 130.1 & 1.25 & 30.7 \\
\hline 9 & 290 & 300 & 0.435 & 162.5 & 124.1 & 129.5 & 1.42 & 30.5 \\
\hline 10 & 300 & 350 & 0.809 & 159.3 & 121.8 & 127.0 & 1.64 & 30.2 \\
\hline 11 & 350 & 400 & 1.40 & 154.3 & 118.2 & 123.2 & 2.01 & 29.7 \\
\hline 12 & 400 & 450 & 1.93 & 149.7 & 115.0 & 119.7 & 2.38 & 29.3 \\
\hline 13 & 450 & 500 & 2.43 & 145.3 & 111.9 & 116.5 & 2.75 & 28.8 \\
\hline 14 & 500 & 550 & 2.90 & 141.1 & 109.0 & 113.4 & 3.14 & 28.3 \\
\hline 15 & 550 & 600 & 3.37 & 137.0 & 106.1 & 110.3 & 3.70 & 27.7 \\
\hline 16 & 600 & 650 & 3.84 & 132.9 & 103.1 & 107.2 & 4.29 & 26.9 \\
\hline 17 & 650 & 700 & 4.30 & 128.8 & 100.2 & 104.1 & 4.76 & 26.4 \\
\hline 18 & 700 & 750 & 4.76 & 124.8 & 97.4 & 101.1 & 5.20 & 25.8 \\
\hline 19 & 750 & 800 & 5.20 & 121.0 & 94.5 & 98.1 & 5.66 & 25.3 \\
\hline 20 & 800 & 850 & 5.63 & 117.2 & 91.8 & 95.2 & 6.12 & 24.7 \\
\hline 21 & 850 & 900 & 6.05 & 113.5 & 89.1 & 92.4 & 6.58 & 24.1 \\
\hline 22 & 900 & 950 & 6.45 & 110.0 & 86.6 & 89.8 & 7.10 & 23.5 \\
\hline 23 & 950 & 1000 & 6.83 & 106.7 & 84.2 & 87.2 & 7.64 & 22.9 \\
\hline 24 & 1000 & 2000 & 7.01 & 105.1 & 83.0 & 86.0 & 7.91 & 22.6 \\
\hline
\end{tabular}

1 - SOP is start of operations (Dec. 1995), SIC is start of institutional control (2026), EIC is end of institutional (2126). 


\subsection{Analysis Assumptions}

Various simplifications were made for this analysis. Some of the more important items are:

- Only $K_{d}$ values without the presence of CDP were considered (i.e., CDP off);

- Uniform distribution of waste was assumed;

- All waste inventory was assumed buried at start of operations; and

- Soil mounded around waste at Option 1 was assumed to be clayey.

Table 2-8 contains the common timeline employed for vadose zone and aquifer flow and transport analyses. An extra 1,000 years was employed in case peak concentrations occurred after the performance period. The key points in time are defined as:

- $\mathrm{SOP}$ - start of operations

- $\quad$ SIC - start of institutional control

- EIC - end of institutional control

- $\quad$ EPP - end of performance period

Table 2-8 Timeline in terms of absolute and relative times employed.

\begin{tabular}{|c|c|c|r|}
\hline Event & Date & Time & Relative Time \\
\hline \hline SOP & $12 / 21 / 1995$ & 1996.0 & $0 \mathrm{yrs}$ \\
\cline { 2 - 4 } ET \#3 & $10 / 1 / 2013$ & 2013.8 & $18 \mathrm{yrs}$ \\
\cline { 2 - 4 } SIC & $12 / 20 / 2025$ & 2026.0 & $30 \mathrm{yrs}$ \\
\cline { 2 - 4 } EIC & $12 / 21 / 2125$ & 2126.0 & $130 \mathrm{yrs}$ \\
\cline { 2 - 4 } EPP & $12 / 29 / 3125$ & 3126.0 & $1130 \mathrm{yrs}$ \\
\cline { 2 - 4 } End & $1 / 5 / 4126$ & 4126.0 & $2130 \mathrm{yrs}$ \\
\hline
\end{tabular}

Note that all inventories were buried uniformly in space over each disposal unit considered. The burial process also assumed that these inventories were all buried at a single point in time (i.e., at the estimated start up time for ET \#3 of 10/1/2013).

For limits and doses the following time windows were chosen (the BG windows were based on isolating the dominant $\mathrm{H}-3$ peak):

- BG1 - Beta-gamma time window 1 set to the interval 2013.8 to 2100.0;

- BG2 - Beta-gamma time window 2 set to the interval 2100.0 to 3126.0; and

- AP - All-pathways time window 1 set to the interval 2126.0 to 3126.0.

\subsection{Vadose Zone Analysis}

For each parent nuclide PORFLOW flow and transport vadose zone analyses were performed for each of the five disposal units. The contaminant flux to water table results from these simulations were then employed to perform aquifer analyses described in Chapter 4. As mentioned in Chapter 2, only the CDP off case was considered. However, both intact and subsidence scenarios were addressed consistent with previous E-Area slit and engineered trench analyses (e.g., see PA, 2008).

\subsection{Conceptual Model}

The basic conceptual models for all five disposal units were essentially the same (e.g., the material zones and timelines). However, geometrical differences as shown in Figure 3-1, produced infiltration rate differences as discussed in Chapter 2. In Figure 3-1 all five crosssections are to scale. The location of the original land surface is highlighted indicating Option 1's uniqueness. Key geometry differences are listed in Table 3-1. Considering the $\mathrm{K}_{\mathrm{d}}$ values listed in 
Table 2-6 and the transport distances listed in Table 2-4, generally the more mobile species (i.e., H-3, I-129, and Tc-99) produced lower fluxes to the water table for Options 1-2-3 due to longer total distances while the less mobile species (i.e., C-14, Np-237, and Sr-90) produced lower fluxes for Options 1 and 4 due to longer clay distances.

Table 3-1 Key geometrical differences among disposal units.

\begin{tabular}{|c|c|c|c|c|c|}
\hline Disposal Unit & $\begin{array}{c}\text { Trench width } \\
\text { (ft) }\end{array}$ & $\begin{array}{c}\text { Crusher run } \\
\text { thickness below } \\
\text { waste } \\
\text { (ft) }\end{array}$ & $\begin{array}{c}\text { Sandy (LVZ) } \\
\text { thickness below } \\
\text { waste } \\
\text { (ft) }\end{array}$ & $\begin{array}{c}\text { Clayey (UVZ) } \\
\text { thickness below } \\
\text { waste } \\
\text { (ft) }\end{array}$ & $\begin{array}{c}\text { Total thickness } \\
\text { below waste } \\
\text { (ft) }\end{array}$ \\
\hline \hline ET \#1 & 160.0 & 1 & 34 & 0 & 35 \\
Option 1 & 200.0 & 1 & 28 & 22 & 51 \\
Option 2 & 150.0 & 1 & 45 & 0 & 46 \\
Option 3 & 157.0 & 1 & 45 & 0 & 46 \\
Option 4 & 200.0 & 1 & 20 & 6 & 27 \\
\cline { 2 - 6 }
\end{tabular}

Figure 3-1 shows all options with different material regions in different colors. Figure 3-1 is for times prior to the EIC, while Figure 3-2 is for times after EIC under an intact scenario. For the subsidence scenario, the materials for the right-most ten feet of the waste zone take on the properties of the initial cover material.

The main material property changes after EIC are the result of dynamic compaction, namely:

- Waste container zone with an original thickness of 16 feet is reduced to $2.5 \mathrm{ft}$;

- Backfill soil above the waste zone is dynamically compacted;

- Backfill soil above side slopes is converted to controlled compacted backfill; and

- During a subsidence event previous overlying material falls into the resulting hole.

Table 2-5 lists the key hydraulic properties employed for the various color-coded regions in Figures 3-1 and 3-2. 


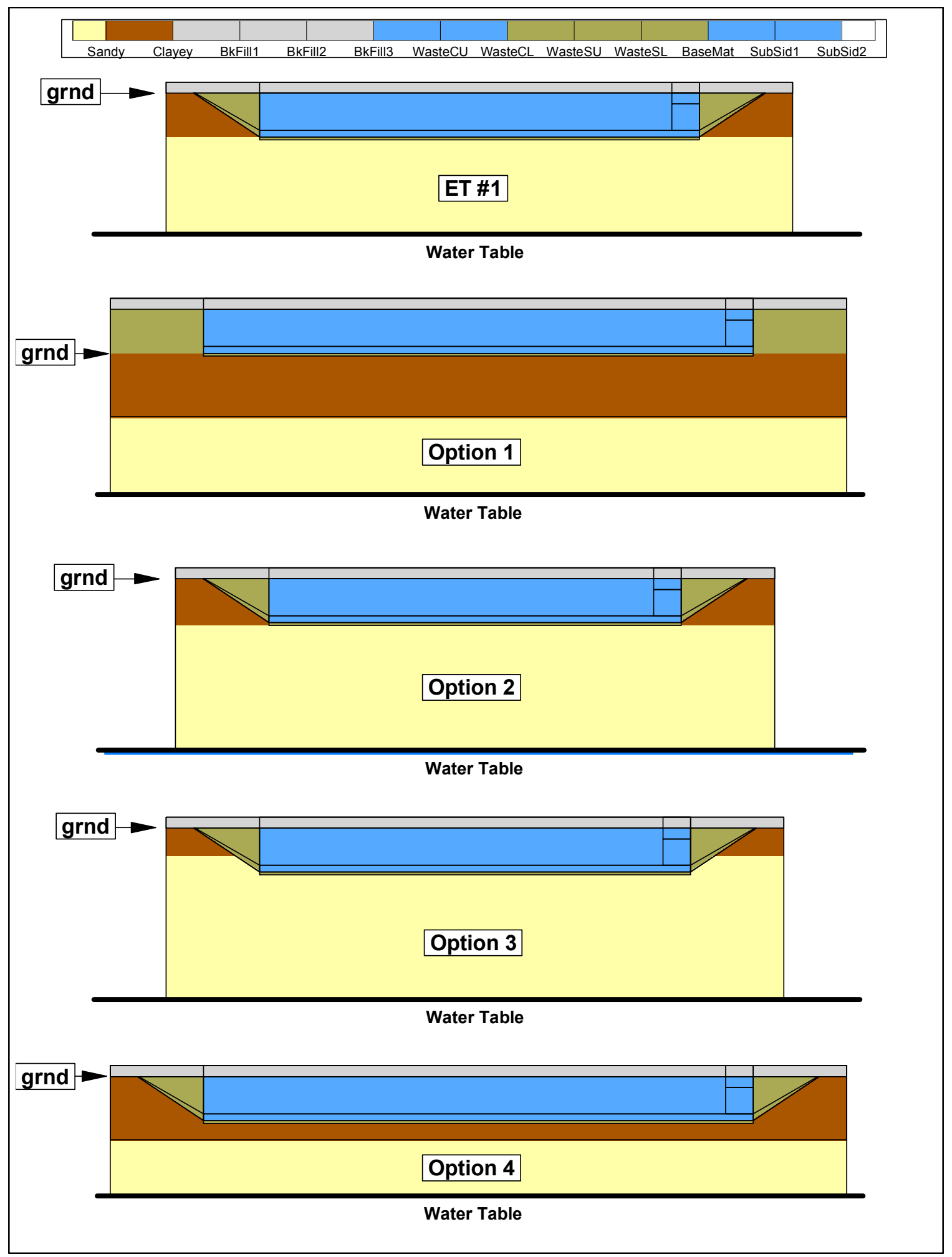

Figure 3-1 Cross-sectional view of each disposal unit within the vadose zone (to scale) where material properties are color coded for conditions before EIC. 


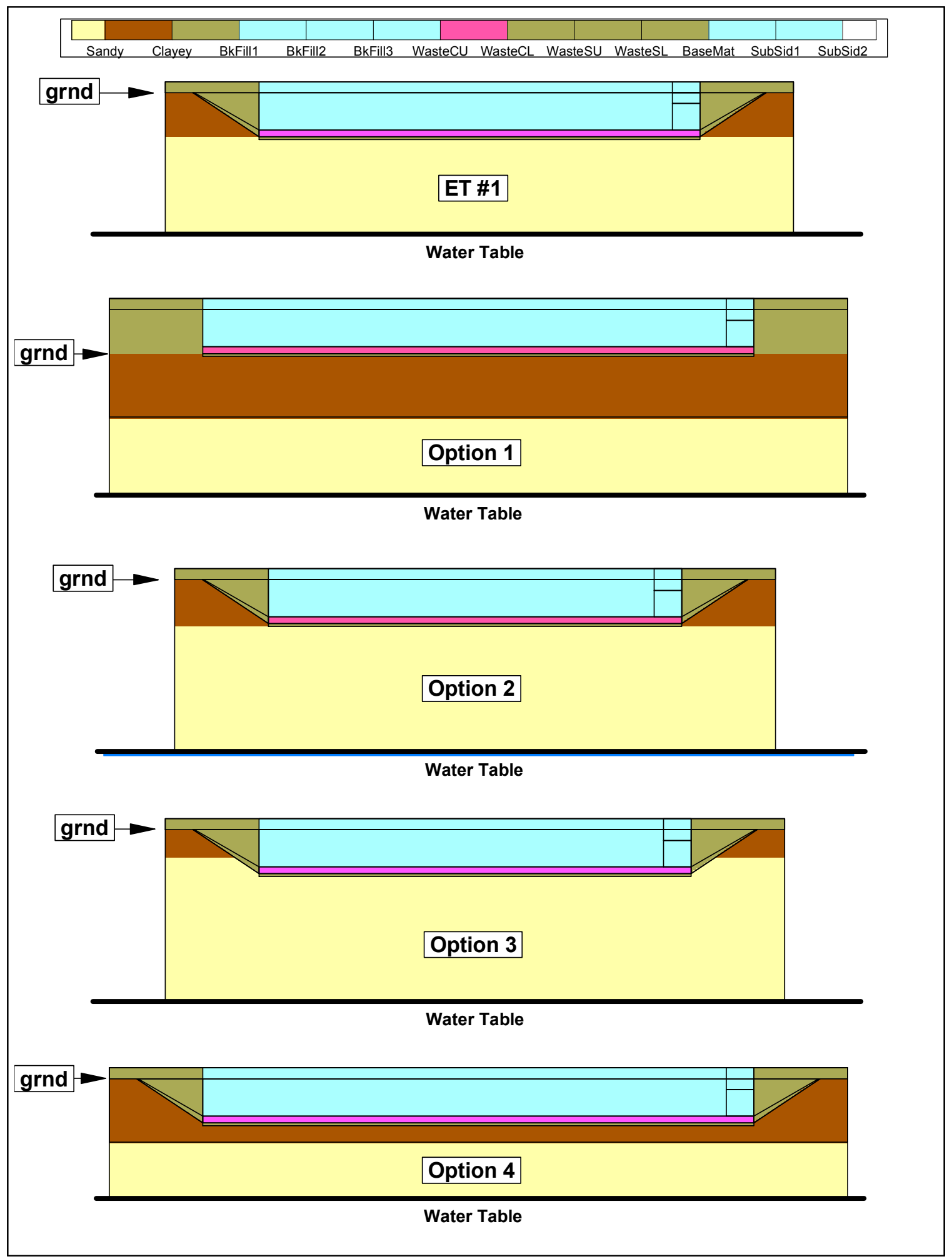

Figure 3-2 Cross-sectional view of each disposal unit within the vadose zone (to scale) where material properties are color coded for conditions after EIC. 


\subsection{Flow Results}

In order to perform transient vadose zone transport simulations, a series of steady-state flow profiles were required over the 24 time periods as shown by the time-dependent infiltration rates listed in Table 2-7. Each of the five disposal units required a unique set of flow solutions (i.e., 24 for the intact scenario and 24 for the subsided scenario). Representative examples of the flow profiles for two time periods are shown in Figure 3-3, where Option 3 results were selected.

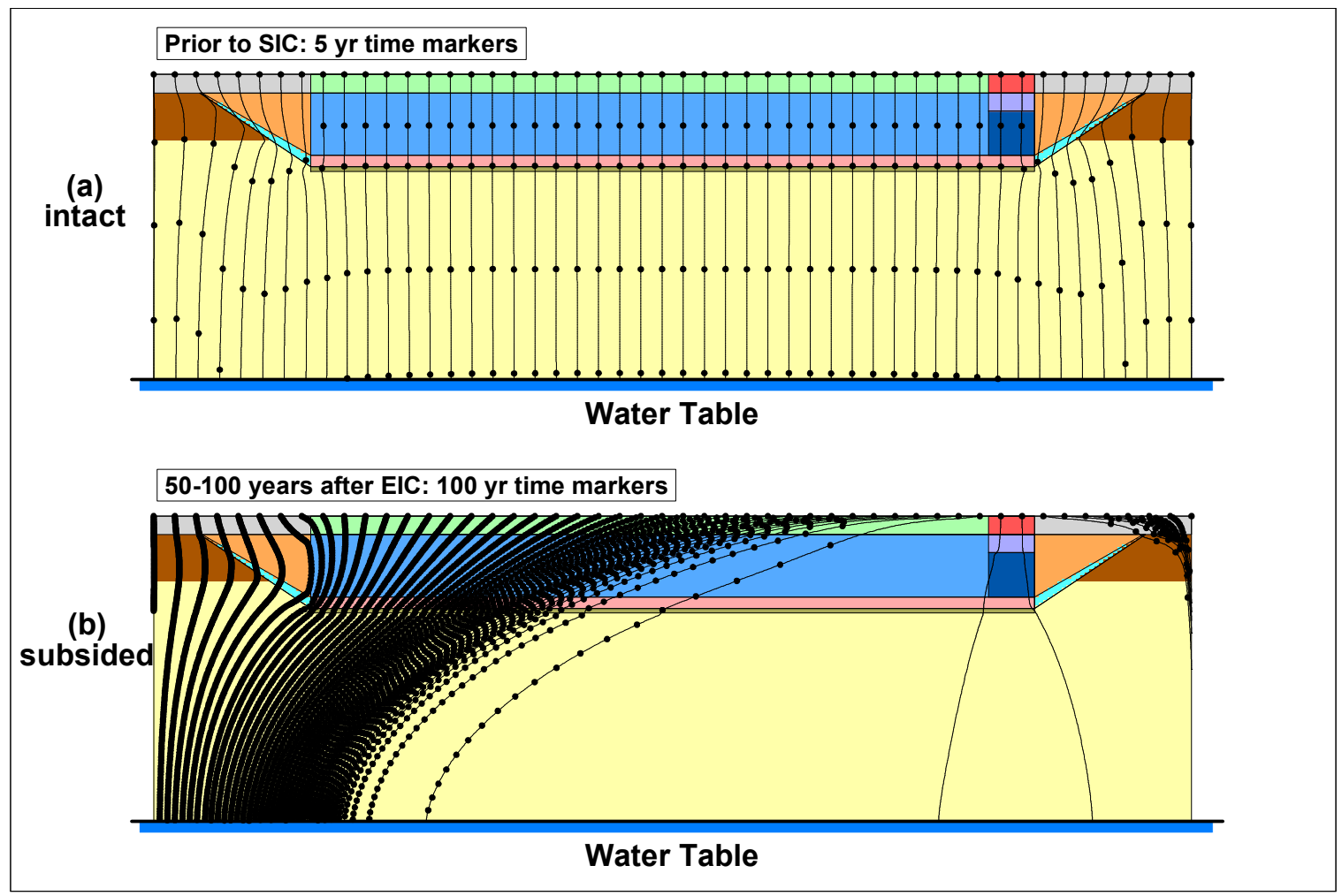

Figure 3-3 (a) Intact and (b) subsided example vadose zone flow profiles for two time periods for Option 3 with 5-year and 100-year time markers, respectively.

The two time periods chosen show the basic behavior for all other time periods and disposal units. Specifically, the following highlights for the chosen time periods are:

- Intact prior to SIC - Here the engineered trench is covered with only soil, no final cap is present. The flow profile is approximately uniform over the width of the trench with a slight funneling effect occurring at the edges. This can be seen by viewing the 5-year time markers that represents the travel time based on pore velocity.

- Subsided 50 to 100 years after EIC - Here the engineered trench experiences subsidence in a ten-foot wide section located along the far right side edge of its waste zone. 100-year time markers are employed showing the profound contrast of the flow profile resulting from a local subsidence condition. Approximately half the waste zone on the right side experiences a significant increase in water movement from an infiltration rate of 132 in/yr over the 10-ft wide section versus $0.0077 \mathrm{in} / \mathrm{yr}$ over the rest of the upper surface. 


\subsection{Transport Results}

Transient vadose zone transport simulations were performed for each of the five disposal units: starting in the year 2013 (first expected burial in ET \#3) to the year 4126 (1,000 years beyond the end of the performance assessment period. See Table 2-8 for the basic simulation timeline. Both intact and subsided scenarios were considered for the CDP off case only.

To remain consistent with prior analyses (e.g., the PA approach), a "blended" flux to the water table was created for the actual subsidence scenario. The blended case was a mix of the intact results $(90 \%)$ and the subsided results $(10 \%)$ in an attempt to reflect the overall $10 \%$ of noncrushable containers allowed within a trench unit (prior to the EIC fluxes are identical for all cases). Representative flux to the water table results (for $1 \mathrm{Ci}$ of parent buried) are shown for Option 3 in Figures 3-4 through 3-9. For each parent nuclide the following fluxes to the water table are shown where off refers to the CDP off state:

- Intact condition (Case01_off; solid blue curves);

- Subsided condition (Case11_off; dashed red curves); and

- Blended condition (Case01n11_off; dashed green curves).

For Np-237 note that Figure 3-7 shows its three chain members in differing colors: Np-237 (blue), U-233 (green), and Th-229 (red). Due to decay H-3 fluxes shown in Figure 3-5 only extend to year 2600 .

To illustrate the basic differences seen among options for transport through the vadose zone, the results for I-129 were chosen and are provided in Figure 3-10. I-129 was chosen due to its long half-life and low $\mathrm{K}_{\mathrm{d}}$ values (i.e., it approaches the behavior of an ideal conservative tracer). The flux to water table curves shown in Figure 3-10 are consistent with the sandy, clayey, and total transport lengths listed in Table 2-4. For example, Option 1 has the longest clayey and total transport lengths and its peak flux to water table is delayed the longest time.

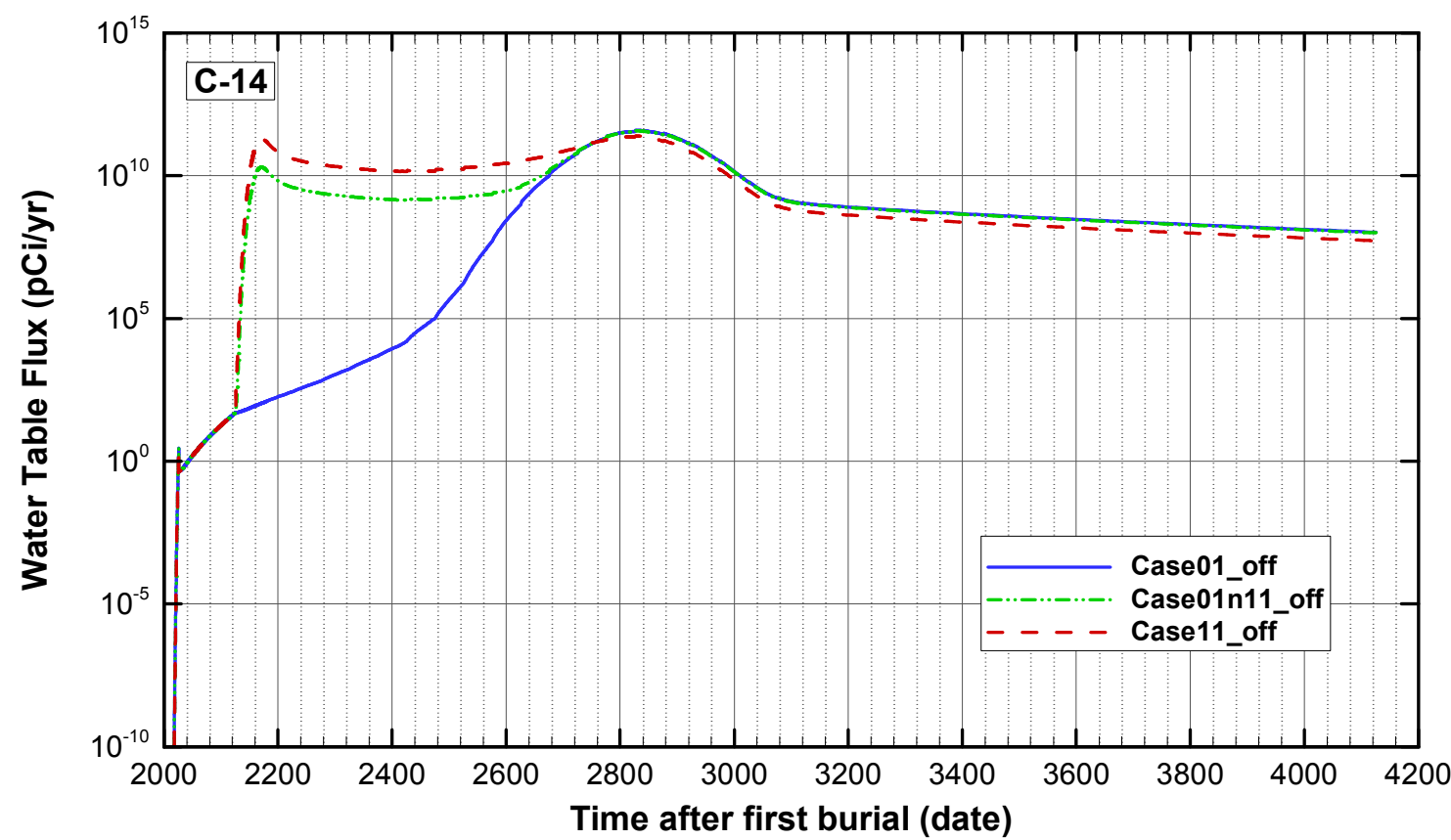

Figure 3-4 C-14 flux to the water table for Option 3 showing the intact, subsided, and blended results. 


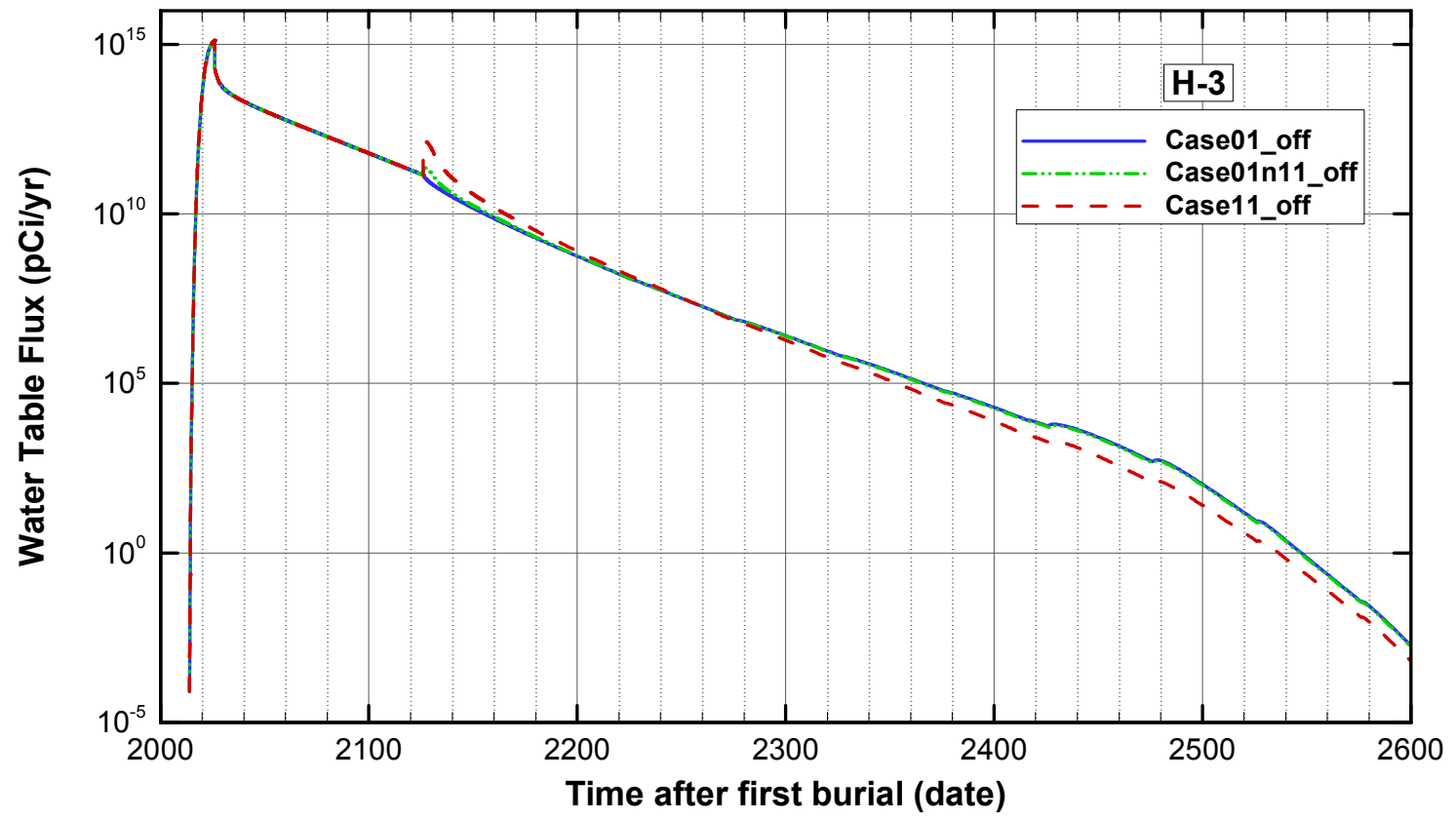

Figure 3-5 H-3 flux to the water table for Option 3 showing the intact, subsided, and blended results.

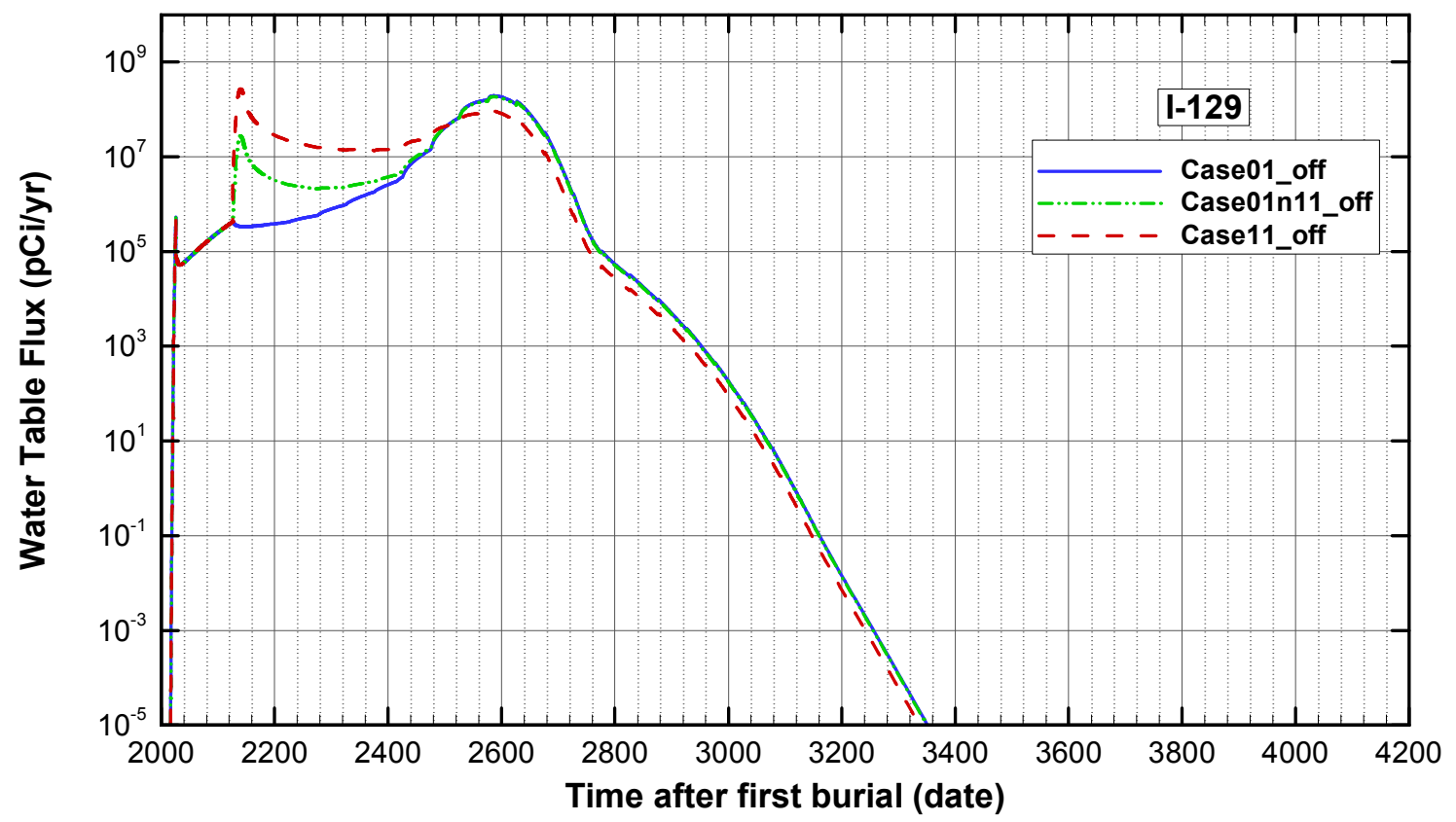

Figure 3-6 I-129 flux to the water table for Option 3 showing the intact, subsided, and blended results. 


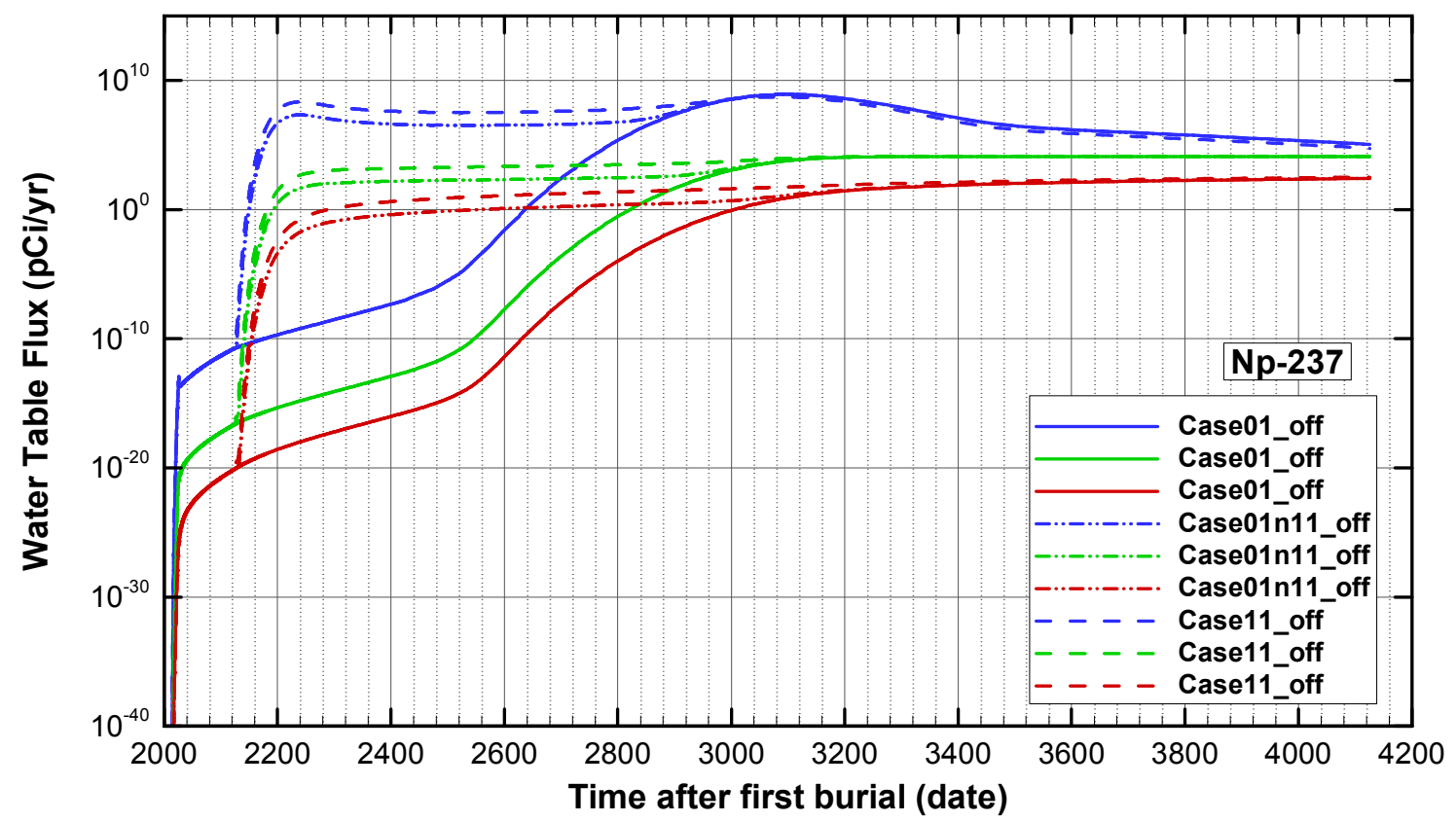

Figure 3-7 Np-237 flux to the water table for Option 3 showing the intact, subsided, and blended results (Np-237 - blue, U-233 - green, and Th-229 - red).

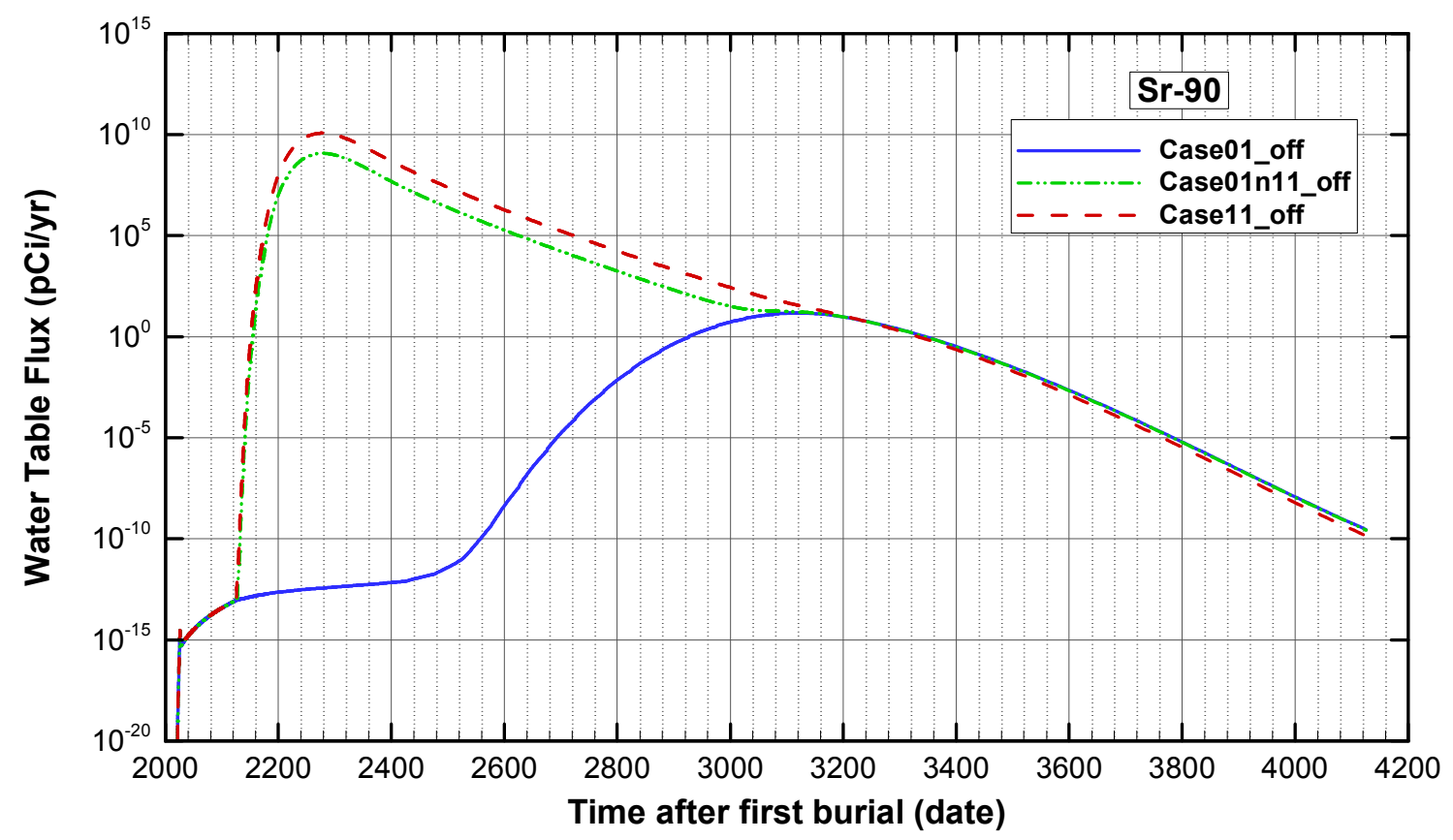

Figure 3-8 Sr-90 flux to the water table for Option 3 showing the intact, subsided, and blended results. 


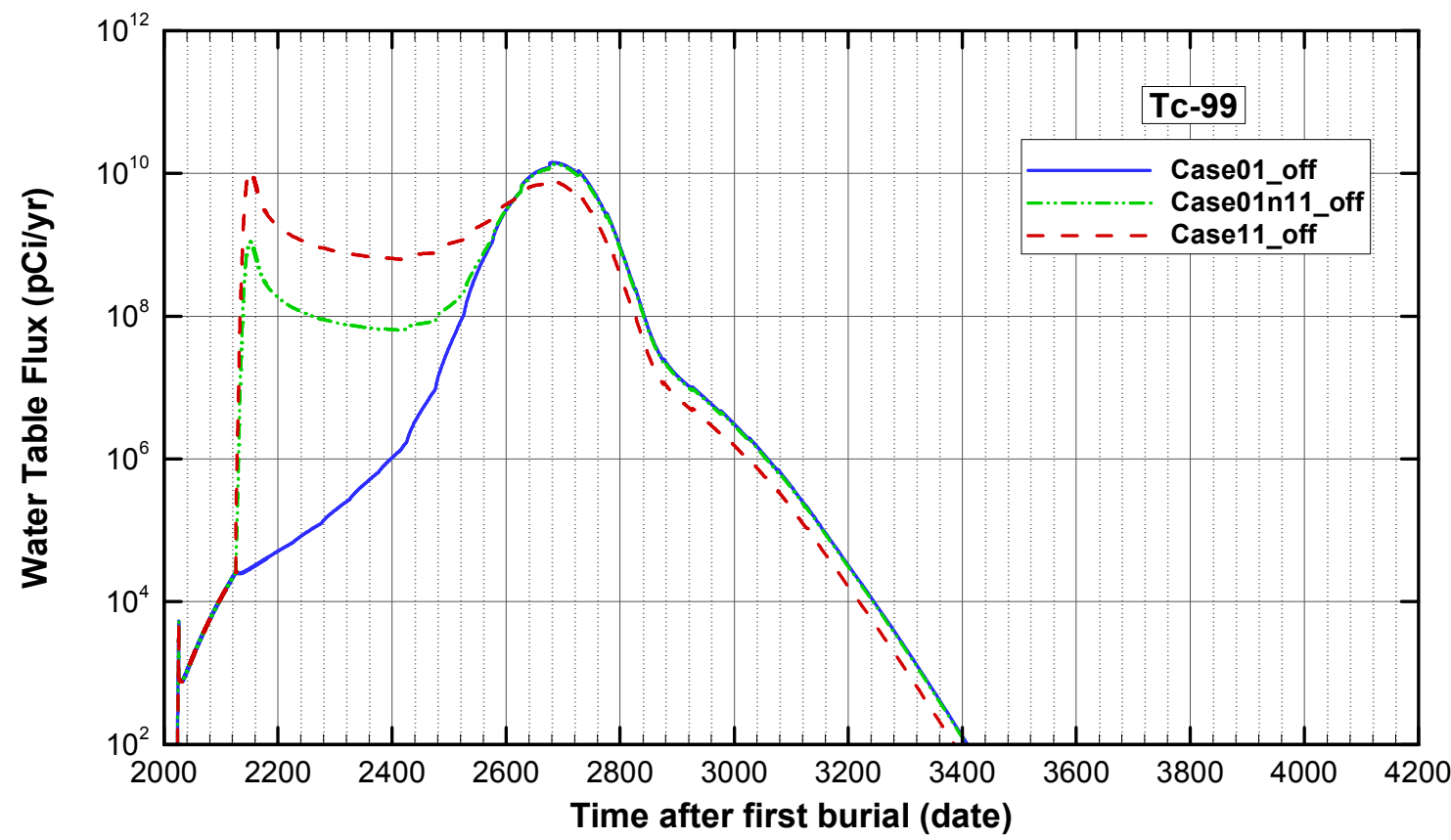

Figure 3-9 Tc-99 flux to the water table for Option 3 showing the intact, subsided, and blended results.

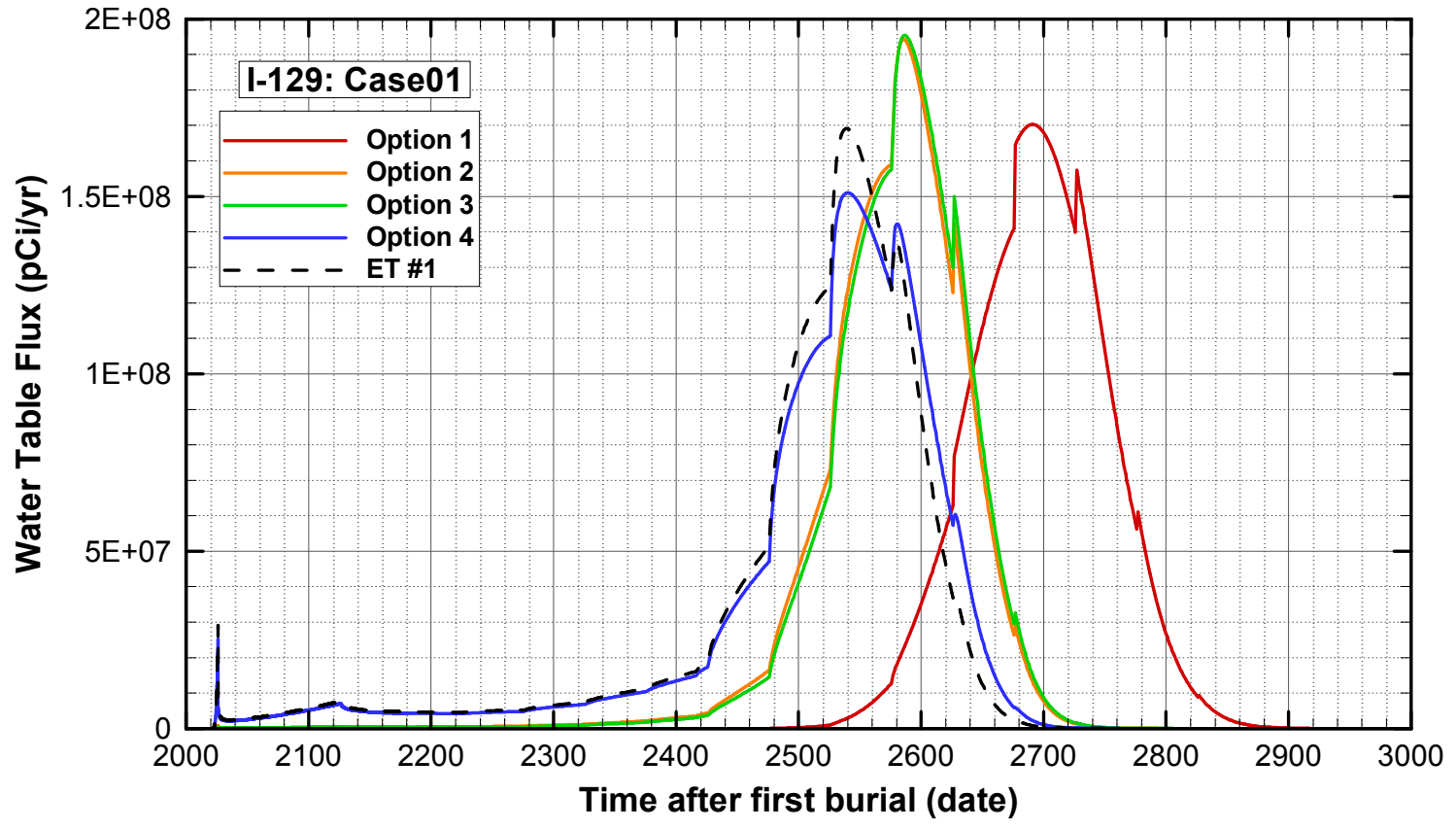

Figure 3-10 I-129 flux to the water table for each disposal unit under the intact (Case01_off) condition. 


\subsection{Aquifer Analysis}

For each parent nuclide, 3D PORFLOW transport aquifer analyses were performed for each of the five disposal units. The flux to water table results from the $2 \mathrm{D}$ vadose zone analyses described in Chapter 3 were employed as source terms. They were applied at the source node locations (i.e., nodes located beneath the disposal unit footprint and just below the surface of the water table) for each disposal unit considered, then transport simulations for each disposal unit were performed separately. The degree of plume overlap was not addressed here explicitly. Instead, plume overlap (i.e., plume interaction) was calculated (in Chapter 5) and was incorporated as a simple constant multiplication factor (in Chapter 6) for the maximum well concentrations obtained from the aquifer results (i.e., a post-PORFLOW application).

As mentioned in earlier chapters, for each disposal unit and parent nuclide the following aquifer transport simulations were performed to support the down-select process:

- Only CDP off case was considered;

- An intact (Case01) and a 10\% subsided (Case01n11; "blended") case were considered; and

- For Option 1 a "local" 100-meter boundary and the "E-Area" boundary were both considered separately.

To illustrate the transport behavior of the aquifer system beneath the E-Area, concentration profiles for I-129 were chosen for each disposal unit (because it represents the closest nuclide to an ideal tracer). In Figures 4-1 and 4-2 a consistent range of concentration contours are plotted for all disposal units. For each option, a year close to when the peak well concentration occurred was selected (i.e., year 2740 for Option 1, year 2600 for Options 2 and 3, and year 2560 for Option 4 and ET \#1). For each option a plane of aquifer nodes was selected that exemplified the transport behavior. Each disposal unit's plume represents a given plane of aquifer nodes within the model (e.g., the $8^{\text {th }}$ plane which varies from $\sim 80$ to $\sim 90$ feet below ground surface for Option 1). For the other options other node planes were selected as needed to best show the results.

As both figures indicate, a modest amount of lateral dispersion results during the migration of I129 (i.e., from its source at the surface of the water table and then reaching the 100-meter boundary). The maximum well concentrations (incorporating the plume interaction factor) beyond the 100-meter boundary are plotted versus time in Figures 4-3 through 4-8 for each parent nuclide. Note that only Np-237 is plotted in Figure 4-6, not its progeny. The peak times used in Figures 4-1 and 4-2 were based on the Figure 4-5 plots. The following observations can be made from Figures 4-3 through 4-8:

- C-14 - Option 1 transport times through the vadose zone become significant due to the increased clay and total depths as listed in Table 2-4. Option 4 concentration is still rising significantly at the end of the performance period.

- H-3, I-129, Np-237, and Tc-99 - Option 4 transport time through the vadose and aquifer systems is short relative to the others yielding a much larger peak concentration value.

- Sr-90 - Option 4 shows a much higher sensitivity to subsidence. 


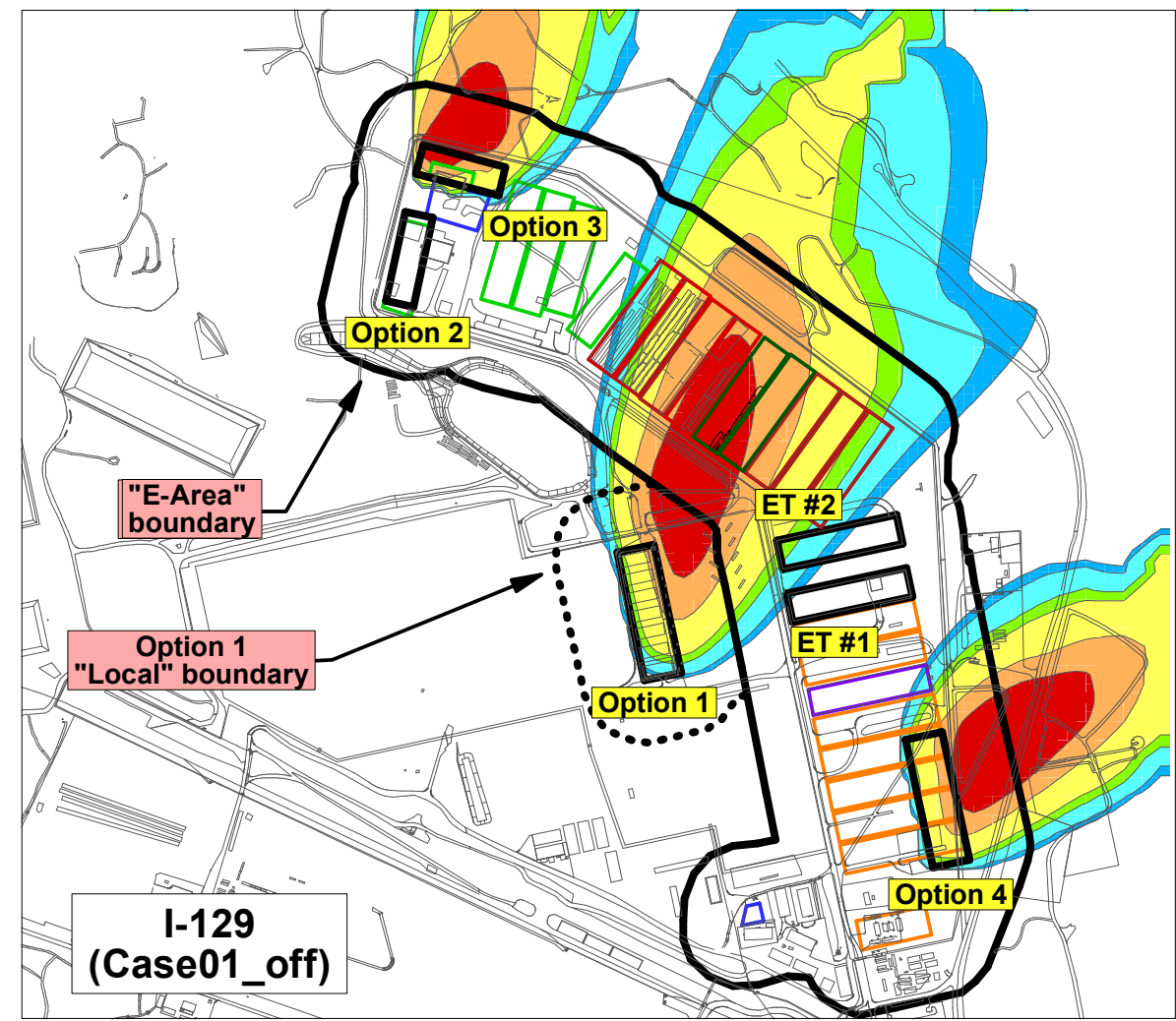

Figure 4-1 I-129 aquifer concentration profiles for Options 1, 3, and 4 (Case01_off condition) near their times of peak maximum well concentrations.

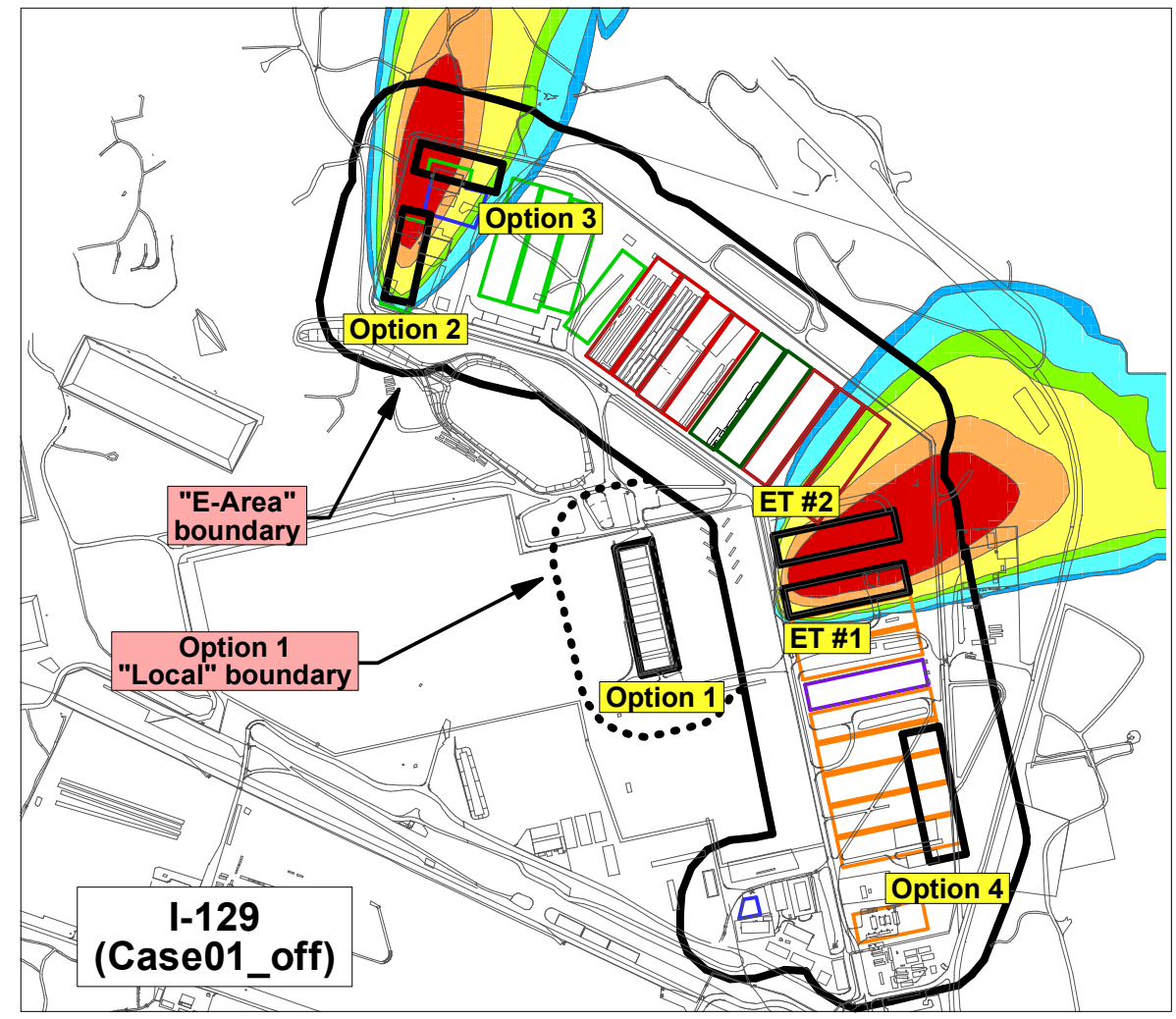

Figure 4-2 I-129 aquifer concentration profiles for Option 2 and ET \#1 (Case01_off condition) near their times of peak maximum well concentrations. 


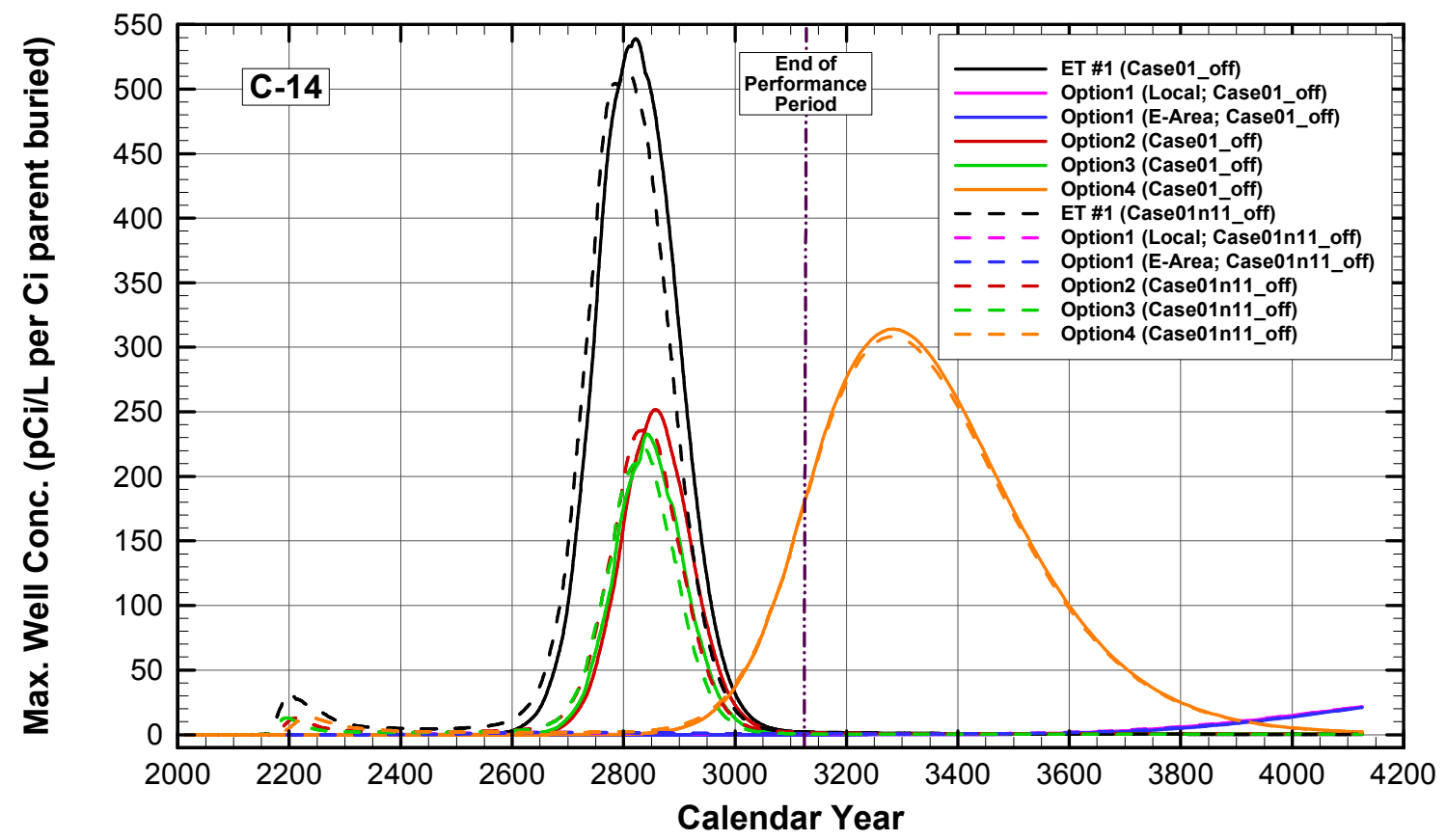

Figure 4-3 Maximum well concentrations vs. time, incorporating the plume interaction factor, for C-14 showing the intact (Case01_off) and 10\% blended (Case $01 n 11 \_$off) results.

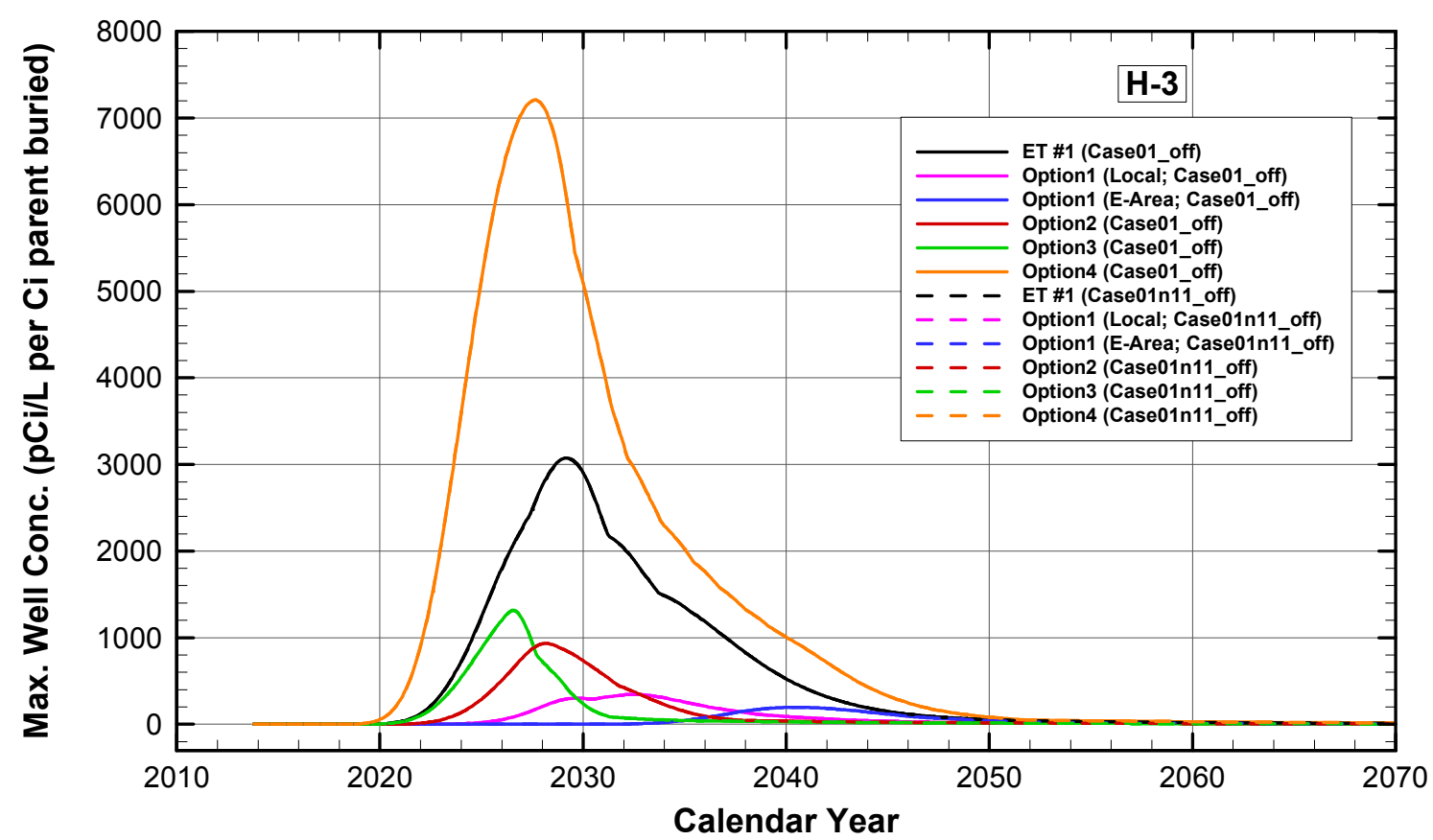

Figure 4-4 Maximum well concentrations vs. time, incorporating the plume interaction factor, for H-3 showing the intact (Case01_off) and 10\% blended (Case01n11_off) results. 


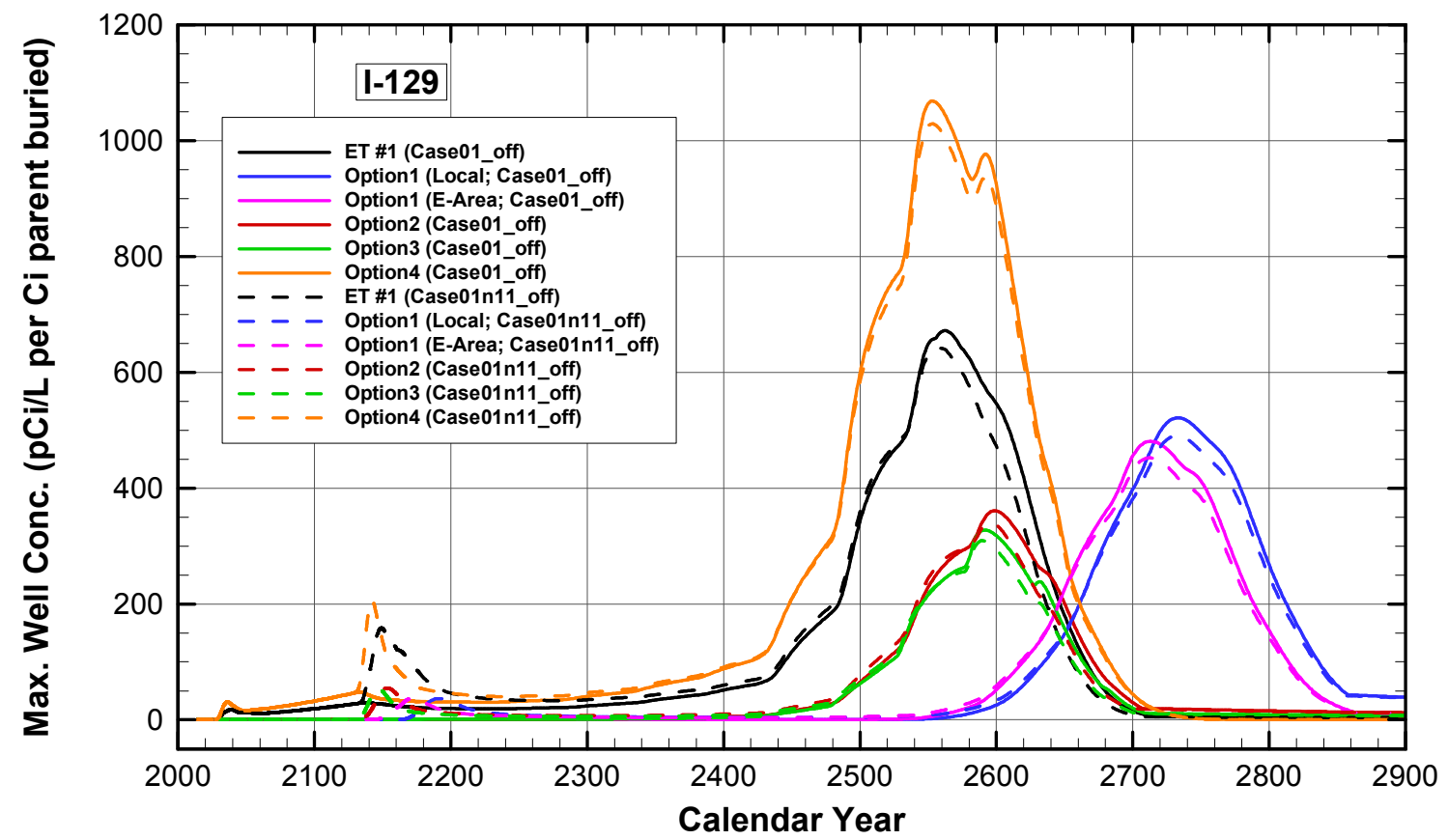

Figure 4-5 Maximum well concentrations vs. time, incorporating the plume interaction factor, for I-129 showing the intact (Case01_off) and 10\% blended (Case01n11_off) results.

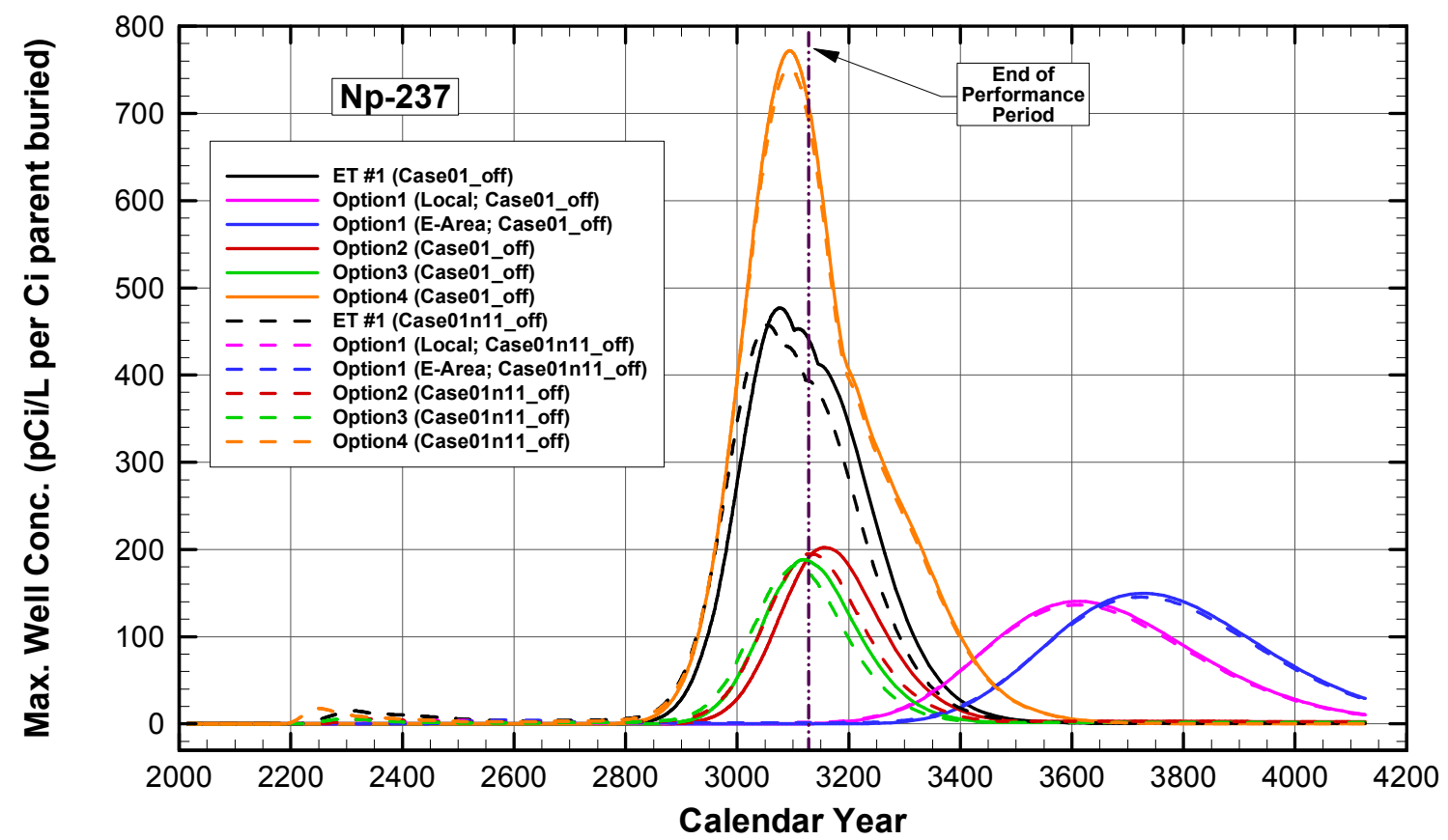

Figure 4-6 Maximum well concentrations vs. time, incorporating the plume interaction factor, for Np-237 showing the intact (Case01_off) and 10\% blended (Case01n11_off) results. 


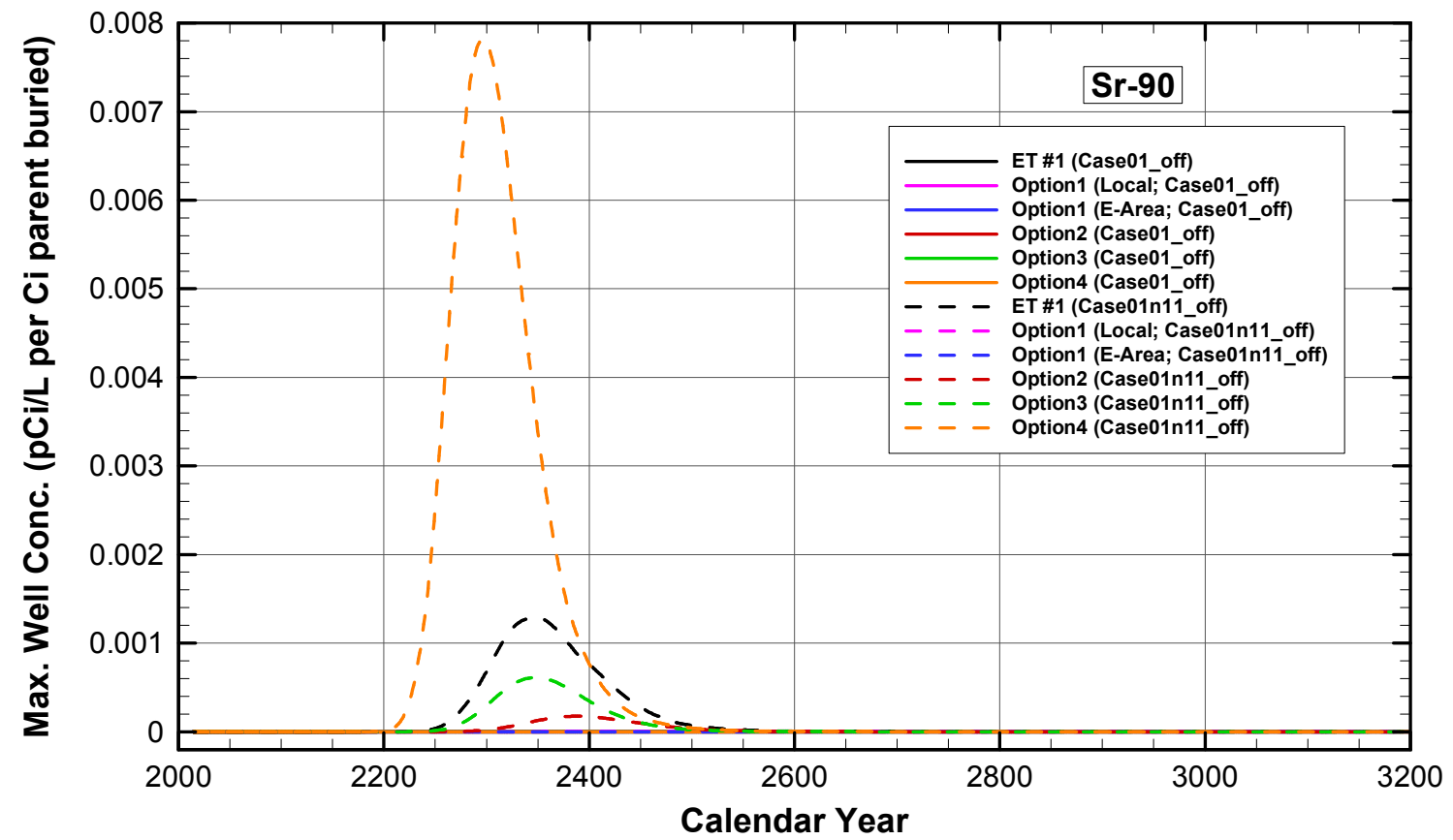

Figure 4-7 Maximum well concentrations vs. time, incorporating the plume interaction factor, for Sr-90 showing the intact (Case01_off) and 10\% blended (Case01n11_off) results.

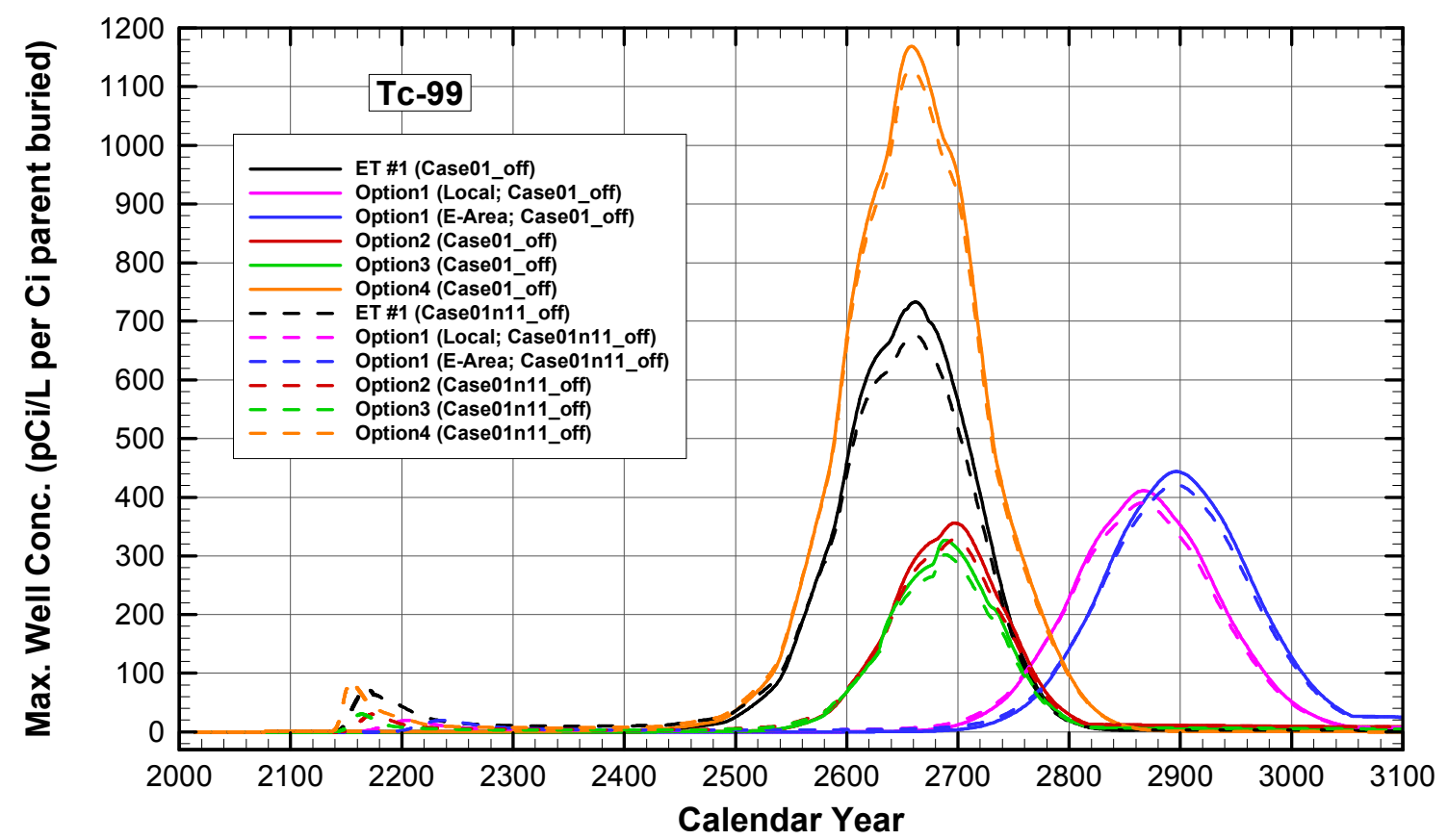

Figure 4-8 Maximum well concentrations vs. time, incorporating the plume interaction factor, for Tc-99 showing the intact (Case01_off) and 10\% blended (Case $01 n 11 \_$off) results. 


\subsection{Plume Interaction}

\subsection{Method}

Because separate PORFLOW aquifer models were run for each option, plume interaction effects were incorporated via post-processing. Plume interaction factors were estimated as wellconcentration multipliers (i.e., disposal-unit-specific factors that are time and nuclide independent) for each option employing the two-step modeling method used in the PA.

Consistent with the PA (2008) approach, in the first step inventory in the form of constant-rate sources was uniformly applied across the footprint of a single option. That inventory magnitude was adjusted until the peak well concentration at any location beyond the E-Area $100-\mathrm{m}$ buffer matched a pseudo-MCL of $1.14 \mathrm{E}-8 \mathrm{~mol} / \mathrm{L}$.

In the second step all E-Area disposal units were modeled simultaneously. The inventory magnitudes for the non-option disposal units were fixed at the inventory levels used in the PA plume interaction analysis. (This fixation preserved the inventory limits for all of the non-option disposal units.) The inventory magnitude for the option was adjusted until the peak well concentration at any location beyond the E-Area 100-m buffer matched a pseudo-MCL of $1.14 \mathrm{E}-8 \mathrm{~mol} / \mathrm{L}$.

The plume interaction factor was calculated as the option inventory magnitude from Step 1 divided by the option inventory magnitude from Step 2. For example, if Option 1 by itself needed an inventory magnitude of 2 moles to generate a peak well concentration of $1.14 \mathrm{E}-8$ $\mathrm{mol} / \mathrm{L}$ but only an inventory magnitude of 1 mole when the other disposal units are included, then its plume interaction factor was 2 ( 2 mole $/ 1$ mole).

The contaminant used in this analysis was a conservative tracer (non-decaying and un-retarded). The PA used a pseudo-MCL of 1.0E-8 mol/L. However, the current analysis used a pseudo-MCL of $1.14 \mathrm{E}-8 \mathrm{~mol} / \mathrm{L}$ because the horizontal cell-size for the current analysis was reduced from 67.7 $\mathrm{ft}$ on a side to $50 \mathrm{ft}$ on a side, hence the well concentrations increased. To calculate the current pseudo-MCL a preliminary model was executed where the PA inventories for all disposal units were simultaneously remodeled using the new mesh. The new model generated a peak well concentration of $1.14 \mathrm{E}-8 \mathrm{~mol} / \mathrm{L}$ that became the pseudo-MCL for the new mesh. While the PA used disposal groups (e.g., an ET group that consisted of ET \#1 and ET \#2) the current analysis used disposal units because the options typically were disposal units that were subsets of disposal groups.

\subsection{Results}

Plume interaction factors are provided in Table 5-1 for all the options and ET \#1 (for comparison). Table 5-1 indicates that Option 1 had the most plume interaction, followed closely by Option 4. Options 2 and 3 had the least plume interaction because they are located at the edge of the SlitWest group of slit trenches.

Surprisingly, Option 2's plume interaction factor (1.32) is less than its PA value of 1.90. This reduction implies that if the PA had modeled ST \#13 (the PA equivalent of Option 2) separately, then all its inventory limits would have been about 50 percent higher. Similarly, Option 3 has a plume interaction factor of 1.17 versus its PA value of 1.90, implying that if the PA had modeled ST \#12 (the PA equivalent of Option 3) separately, then all its inventory limits would have been about 60 percent higher. Therefore, from a plume interaction standpoint, Options 2 and 3 are more valuable real estate than was recognized in the PA. 
Table 5-1 Plume interaction factors.

\begin{tabular}{|c|c|}
\hline Option & $\begin{array}{c}\text { Concentration } \\
\text { plume interaction } \\
\text { factor, Step 1/ Step2 } \\
(-)\end{array}$ \\
\hline \hline Option 1 & 3.37 \\
\hline Option 2 & 1.32 \\
\hline Option 3 & 1.17 \\
\hline Option 4 & 2.86 \\
\hline ET \#1 & 1.64 \\
\hline
\end{tabular}

Figure 5-1 displays concentrations along a horizontal slice of the aquifer model where the peak concentrations appeared. This figure is from Step 2.

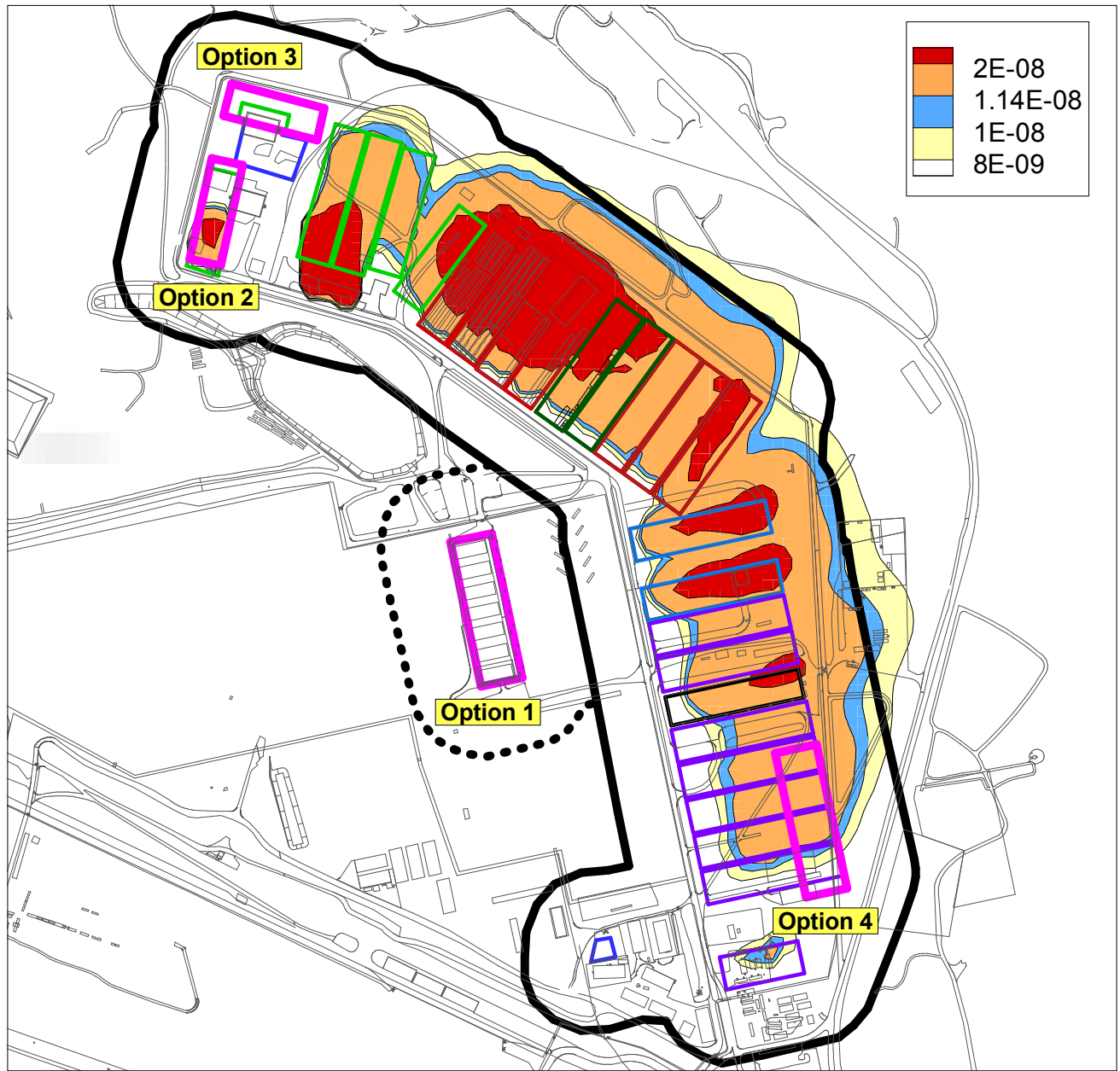

Figure 5-1 Horizontal slice of aquifer model showing concentrations with only Option 4's inventory magnitude varying. 


\subsection{Performance}

\subsection{Quantitative Results}

\subsubsection{Quasi-limits}

Quasi-limits were calculated for each option and for each GW pathway (beta-gamma or all-pathways). These values are termed quasi-limits because simplifying assumptions were selected (e.g., perimeter coordinates and the method to incorporate the effects of non-crushable containers) to complete this comparative study. To produce quasi-limits, three post-PORFLOW processing steps were required as follows:

1. Convert PORFLOW well concentrations from $\mathrm{mol} / \mathrm{ft}^{3}$ per mol of the parent buried to $\mathrm{pCi} / \mathrm{L}$ per $\mathrm{Ci}$ of the parent buried. This step also required creating well concentrations for all radionuclides in the parent chain that were not modeled in PORFLOW (they were assumed to be in secular equilibrium with a precursor). At this step each well concentration was multiplied by its plume interaction factor to produce a magnified well concentration. The plume interaction factor is one for Option 1 in conjunction with its local 100-m boundary (i.e., no plume overlap from neighboring units occurs).

(PORFLOW reports the greatest well concentration for the set of cells outside the 100-m buffer. Therefore at different times, that location can vary, e.g., for a moving H-3 front.)

This step also included selecting the higher magnified well concentration between Case01 (where zero non-crushable containers exist) and Case01n11 (where 10 percent non-crushable containers exist) (i.e., the "worst" case). This was done at each time step.

2. Multiply each magnified well concentration by its dose conversion factor (DCF) to produce a chain member dose. Then sum the chain member doses to produce a total dose for the parent chain.

3. For each parent chain, select the peak total dose for each pathway (and for each time interval if applicable). Multiply the adjusted model inventory of $1 \mathrm{Ci}$ (from Step 1) by the allowable dose (e.g., an MCL for the beta-gamma pathway) and divide by the peak total dose to produce a quasi-limit. For example, if the allowable dose is $4 \mathrm{mrem} / \mathrm{yr}$ and the peak total dose is $2 \mathrm{mrem} / \mathrm{yr}$, then the quasi-limit $(\mathrm{Ci})=1 \mathrm{Ci} * 4 \mathrm{mrem} / \mathrm{yr} / 2 \mathrm{mrem} / \mathrm{yr}$ $=2 \mathrm{Ci}$. At this step the lower limit from both Option 1 analyses (its local 100-m buffer without plume interaction and the E-Area $100-\mathrm{m}$ buffer with plume interaction) was selected for reporting purposes.

Step 2 used newer DCFs (ICRP 1995) than did the PA (2008). Both sets of values are compared in Table 6-1, where the DCFs are presented in order from the highest ratio (i.e., new/old) to the lowest.

Table 6-1 Ingestion Dose Conversion Factors (mrem/yr per pCi/L).

\begin{tabular}{|c|c|c|c|}
\hline Parent & PA DCF & New DCF & New DCF / PA DCF \\
\hline \hline Tc-99 & $7.47 \mathrm{E}-4$ & $1.21 \mathrm{E}-3$ & 1.62 \\
\hline I-129 & $1.41 \mathrm{E}-1$ & $2.08 \mathrm{E}-1$ & 1.48 \\
\hline $\mathbf{H}-3$ & $3.27 \mathrm{E}-5$ & $3.40 \mathrm{E}-5$ & 1.04 \\
\hline $\mathbf{C}-14$ & $1.07 \mathrm{E}-3$ & $1.10 \mathrm{E}-3$ & 1.03 \\
\hline Sr-90 & $7.28 \mathrm{E}-2$ & $5.29 \mathrm{E}-2$ & 0.73 \\
\hline Np-237 & $2.27 \mathrm{E}+0$ & $2.08 \mathrm{E}-1$ & 0.09 \\
\hline
\end{tabular}

The groundwater quasi-limits are shown in Table 6-2 where two time windows were chosen for beta-gamma and one window for all-pathways (see Section 2.6). Quasi-limits from among the 
four options are shaded from lowest being red to highest being dark green (i.e., red, yellow, light green, and dark green). Blue shows where no limits apply (i.e., the actual limit exceeded $10^{20} \mathrm{Ci}$ ).

Option 4 typically has the lowest quasi-limits among the four options. The low quasi-limits are attributed to only having $27 \mathrm{ft}$ of soil beneath the waste, having the second shortest aquifer travel distance, and the second quickest aquifer travel time of 4.3 years. However it does perform well for $\mathrm{C}-14$, because it has 6 feet of clay beneath the waste zone that helps retard C-14 with its clay $\mathrm{K}_{\mathrm{d}}$ of $30 \mathrm{ml} / \mathrm{g}$ vs. Options 2 and 3 containing no clay.

Option 1 usually has the highest limits, although in the later years for H-3, I-129, and Tc-99 it is next to the worst. The higher limits are attributed to having the greatest clay thickness of $22 \mathrm{ft}$, a slight advantage in the total thickness below the waste vs. Options 2 and 3 (a big advantage over Option 4), a big footprint advantage vs. Options 2 and 3 (on par with Option 4) and the slowest aquifer travel time of 10.6 years locally (17.4 years to the down-gradient edge of the E-Area 100$\mathrm{m}$ buffer).

Option 3 generally has higher limits than Option 2 as seen by much more green and no red shading. Option 2 does have higher limits than Option 3 for several of the parents in the later years. The early advantage for Option 3 has minimal benefits, because the early quasi-limits for both options are very high vs. later times (e.g. Tc-99 has quasi-limits of 4.9E6 Ci and 3.2E6 Ci for BG1, but they are $2.8 \mathrm{Ci}$ and $2.5 \mathrm{Ci}$ for $\mathrm{BG} 2$ - a reduction of six orders of magnitude). Options 2 and 3 are quite similar, however, the early flux to the water table is greater for Option 2 because it is slightly narrower ( $150 \mathrm{ft} \mathrm{vs} .157 \mathrm{ft}$ ) and because it has a thicker clay layer adjacent to the waste that tends to funnel water through the waste. Option 3 has a quicker aquifer travel time of 1.9 years vs. 5.7 years (because it is closer to the $100-\mathrm{m}$ boundary) which is offset by a lower plume interaction factor (1.17 vs. 1.32). If disposal operations are delayed or if ET \#3 is not instantaneously filled, then the concentration of any parent from Option 2 that passes the $100-\mathrm{m}$ boundary will be reduced and Option 2 could easily have higher limits than Option 3 for BG1.

Table 6-2 ${ }^{1}$ Groundwater quasi-limits (Ci) for beta-gamma and all-pathways.

\begin{tabular}{|c|c|c|c|}
\hline $\begin{array}{c}\text { Option1 } \\
\text { Parent }\end{array}$ & $\begin{array}{c}\text { BG1 } \\
<\mathbf{2 1 0 0} \mathbf{~ y r}\end{array}$ & $\begin{array}{c}\mathbf{B G 2} \\
\mathbf{2} \mathbf{2 1 0 0} \mathbf{~ y r}\end{array}$ & $\begin{array}{c}\text { AP } \\
\text { All } \mathbf{~ y r}\end{array}$ \\
\hline \hline C-14 & --- & $1.2 \mathrm{E}+03$ & $1.2 \mathrm{E}+03$ \\
$\mathbf{H}-\mathbf{3}$ & $5.8 \mathrm{E}+01$ & $1.3 \mathrm{E}+04$ & $1.6 \mathrm{E}+06$ \\
I-129 & $1.8 \mathrm{E}+04$ & $1.9 \mathrm{E}-03$ & $7.9 \mathrm{E}-02$ \\
Np-237 & --- & $7.1 \mathrm{E}+01$ & $1.2 \mathrm{E}+01$ \\
Sr-90 & --- & $1.9 \mathrm{E}+06$ & $5.1 \mathrm{E}+07$ \\
Tc-99 & $2.3 \mathrm{E}+12$ & $2.0 \mathrm{E}+00$ & $1.9 \mathrm{E}+00$ \\
\hline
\end{tabular}

\begin{tabular}{|c|c|c|c|}
\hline $\begin{array}{c}\text { Option2 } \\
\text { Parent }\end{array}$ & $\begin{array}{c}\text { BG1 } \\
<\mathbf{2 1 0 0} \mathbf{~ y r}\end{array}$ & $\begin{array}{c}\text { BG2 } \\
\mathbf{2} \mathbf{2 1 0 0} \mathbf{~ y r}\end{array}$ & $\begin{array}{c}\text { AP } \\
\text { All } \mathbf{~ r r}\end{array}$ \\
\hline \hline C-14 & $2.0 \mathrm{E}+11$ & $7.9 \mathrm{E}+00$ & $8.1 \mathrm{E}+00$ \\
$\mathbf{H}-\mathbf{3}$ & $2.1 \mathrm{E}+01$ & $1.7 \mathrm{E}+04$ & $2.2 \mathrm{E}+06$ \\
I-129 & $2.0 \mathrm{E}+00$ & $2.8 \mathrm{E}-03$ & $1.1 \mathrm{E}-01$ \\
Np-237 & --- & $1.5 \mathrm{E}+00$ & $2.6 \mathrm{E}-01$ \\
Sr-90 & --- & $4.1 \mathrm{E}+04$ & $1.1 \mathrm{E}+06$ \\
Tc-99 & $3.2 \mathrm{E}+06$ & $2.5 \mathrm{E}+00$ & $2.3 \mathrm{E}+00$ \\
\hline
\end{tabular}

\begin{tabular}{|c|c|c|c|}
\hline $\begin{array}{c}\text { Option3 } \\
\text { Parent }\end{array}$ & $\begin{array}{c}\text { BG1 } \\
<\mathbf{2 1 0 0} \mathbf{~ y r}\end{array}$ & $\begin{array}{c}\text { BG2 } \\
\mathbf{2} \mathbf{2 1 0 0} \mathbf{~ y r}\end{array}$ & $\begin{array}{c}\text { AP } \\
\text { All } \mathbf{~ r r}\end{array}$ \\
\hline \hline C-14 & $3.0 \mathrm{E}+11$ & $8.6 \mathrm{E}+00$ & $8.7 \mathrm{E}+00$ \\
H-3 & $1.5 \mathrm{E}+01$ & $2.0 \mathrm{E}+04$ & $1.8 \mathrm{E}+06$ \\
I-129 & $2.8 \mathrm{E}+00$ & $3.1 \mathrm{E}-03$ & $1.3 \mathrm{E}-01$ \\
Np-237 & --- & $1.6 \mathrm{E}+00$ & $2.7 \mathrm{E}-01$ \\
Sr-90 & --- & $1.2 \mathrm{E}+04$ & $3.0 \mathrm{E}+05$ \\
Tc-99 & $4.9 \mathrm{E}+06$ & $2.8 \mathrm{E}+00$ & $2.5 \mathrm{E}+00$ \\
\hline
\end{tabular}

\begin{tabular}{|c|c|c|c|}
\hline $\begin{array}{c}\text { Option4 } \\
\text { Parent }\end{array}$ & $\begin{array}{c}\text { BG1 } \\
<\mathbf{2 1 0 0} \mathbf{~ y r}\end{array}$ & $\begin{array}{c}\text { BG2 } \\
\mathbf{2} \mathbf{2 1 0 0} \mathbf{~ y r}\end{array}$ & $\begin{array}{c}\text { AP } \\
\text { All } \mathbf{~ r ~}\end{array}$ \\
\hline \hline C-14 & $9.2 \mathrm{E}+16$ & $1.1 \mathrm{E}+01$ & $1.1 \mathrm{E}+01$ \\
$\mathbf{H}-\mathbf{3}$ & $2.8 \mathrm{E}+00$ & $6.7 \mathrm{E}+03$ & $1.1 \mathrm{E}+06$ \\
$\mathbf{I - 1 2 9}$ & $3.2 \mathrm{E}-02$ & $9.4 \mathrm{E}-04$ & $3.8 \mathrm{E}-02$ \\
$\mathbf{N p - 2 3 7}$ & $8.1 \mathrm{E}+17$ & $3.9 \mathrm{E}-01$ & $6.5 \mathrm{E}-02$ \\
Sr-90 & --- & $9.0 \mathrm{E}+02$ & $2.4 \mathrm{E}+04$ \\
\hline Tc-99 & $1.2 \mathrm{E}+04$ & $7.7 \mathrm{E}-01$ & $7.1 \mathrm{E}-01$ \\
\hline
\end{tabular}

${ }^{1}$ Shading ranges from lowest being red to highest being dark green (i.e., red, yellow, light green, and dark green). 


\subsubsection{Base case inventory consumption}

Because no option contained all the highest quasi-limits the mixture of parents became important. The parent inventories for ET \#1 (see Table 2-1) were selected to form a "base case." Those inventories were applied to each option individually to calculate the total dose vs. time and to compare the peak total doses to the performance objectives.

The same three post-PORFLOW processing steps performed to calculate the quasi-limits were repeated, except the ET \#1 inventories replaced the $1 \mathrm{Ci}$ inventory used for the quasi-limits. Results shifted from quasi-limits (where inventories were unknown) to performance in the form of total doses vs. time (where assumed inventories were applied).

Dose fractions are presented in Figure 6-1 for each of the options and also for ET \#1 (if it were to be considered a new option). The fractions are doses divided by their performance measures, or equivalently inventory consumption factors. The figure shows values for both the beta-gamma pathway (for time intervals 1 and 2) and the groundwater all-pathways. Option 4 always has the greatest SOFs, followed by ET \#1. Option 1 (for both its local 100-m buffer without plume interaction and its E-Area 100-m buffer with plume interaction) always has the smallest SOFs, while Options 2 and 3 fall in between Option 1 and ET \#1. BG1 is the most important pathway, with groundwater all-pathways being second and BG2 being the least important.

If the ET \#1 inventory mixture were repeated, Option 1 is the preferred option. However, the inventory mixture may change as seen in Table 2-1 for historical inventories, thus the sensitivities of inventory mixtures were investigated as discussed in the next section.

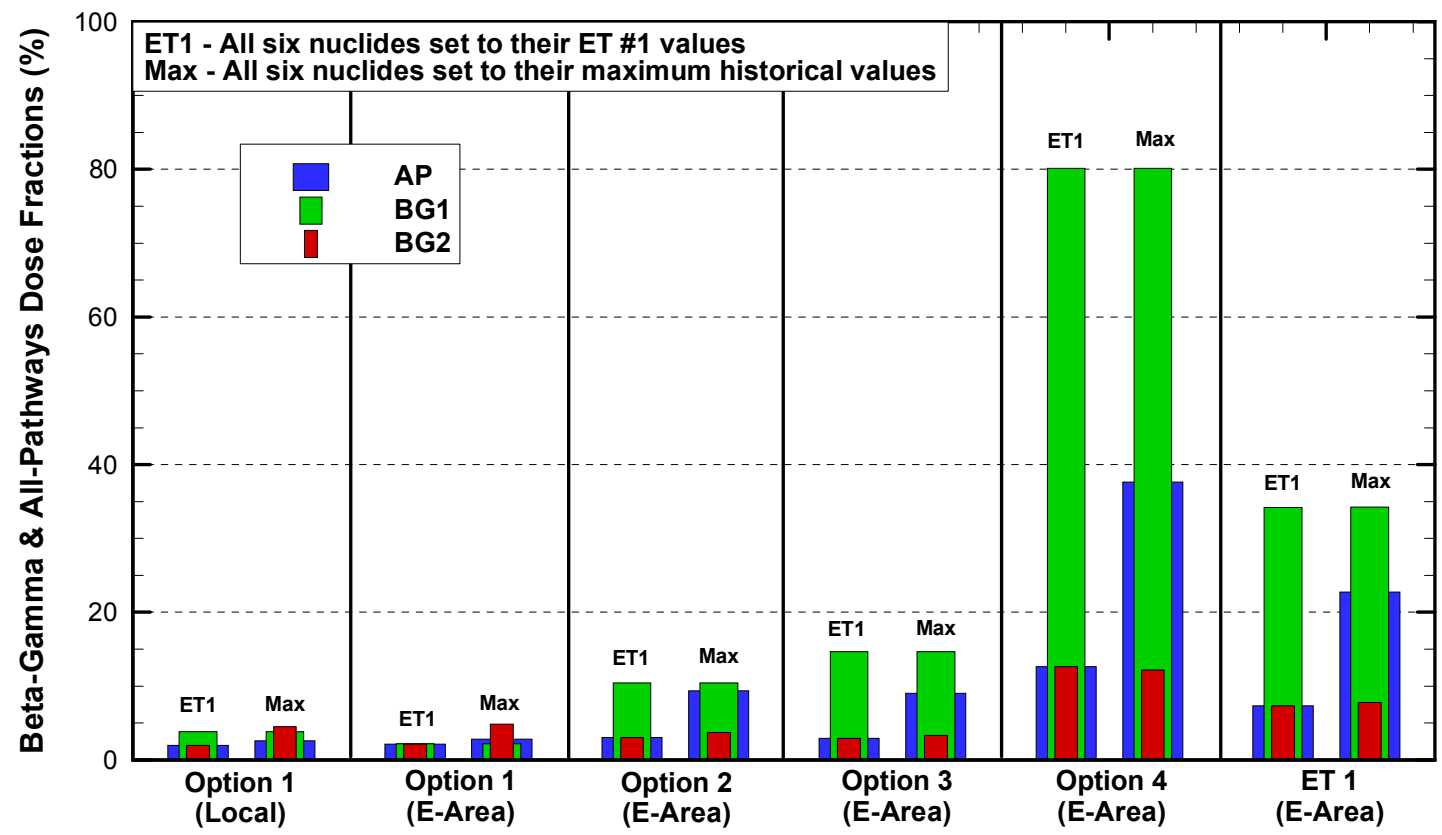

Figure 6-1 Estimated peak beta-gamma and all-pathways SOFs for selected time windows based on (a) ET \#1 inventory and (b) maximum historical inventories. 


\subsubsection{Sensitivities for varying inventory mixtures}

To calculate sensitivities to varying inventory mixtures, the base case (ET \#1) inventory mixture was varied one parent at a time by replacing the selected parent's inventory with its maximum historical inventory. Then PORFLOW post-processing steps were performed to calculate total doses vs. time. The maximum historical inventory for any parent was the greatest inventory disposed in any Engineered Trench or Slit Trench in the E-Area (as of 9/29/2011). One exception was made for H-3 in the SEG boxes which exceeded their original inventory limits. Hence, for ST4, its H-3 inventory was reduced from $8.6 \mathrm{Ci}$ to $0.62 \mathrm{Ci}$ (subtracting the $\mathrm{H}-3$ inventory in the SEG boxes).

Inventories used in the sensitivity analyses and the disposal units with the greatest inventory are shown in

Table 6-3 (extracted from Table 2-1). Because ET \#1 has the greatest inventory for C-14 and H3 , results from those sensitivity analyses are identical to those for the ET \#1 base case inventory shown in Section 6.1.2.

Table 6-3 Inventories (Ci) for sensitivity analyses.

\begin{tabular}{|c|c|c|c|c|c|c|}
\hline & $\mathbf{C}-14$ & $\mathbf{H}-3$ & $\mathbf{I}-129$ & $\mathbf{N p}-237$ & Sr-90 & Tc-99 \\
\hline \hline Max & $1.3 \mathrm{E}-1$ & $2.2 \mathrm{E}+0$ & $9.0 \mathrm{E}-5$ & $2.4 \mathrm{E}-2$ & $4.8 \mathrm{E}+1$ & $5.1 \mathrm{E}-2$ \\
\hline Origin & $\mathrm{ET} \mathrm{\# 1}$ & $\mathrm{ET} \mathrm{\# 1}$ & ST \#8 & ET \#2 & ET \#2 & ST \#4 \\
\hline
\end{tabular}

Analyses were also conducted where every parent was set to its maximum value (from among all STs and ETs) to evaluate an extreme condition. In some cases the total dose results from the maxima inventories did not exceed the total dose results from one of the sensitivity inventory sets. This typically occurred when the less important parents peaked at a much different time than the most important parent.

Results by pathway are presented in Figure 6-2 for each option and also for ET \#1 (if it were to be considered a new option). Each option has its own $\mathrm{x}$-axis spot where column bar charts are plotted, one bar chart for each sensitivity inventory set. As each bar chart was plotted at the same spot, it covered all previous bar charts of equal or smaller magnitude. Therefore, the order of plotting was manipulated so that bar charts were plotted from the highest magnitude to the lowest magnitude and equal magnitudes were noted in a text box. Each figure also has black circles connected by a dashed line that show results for a maximum inventory set where all parent inventories were set to their maximum values.

The upper figure (a) shows peak total doses (i.e., doses from all six parents were combined) for the beta-gamma pathway for time interval 1; the middle figure (b) shows peak total doses for the beta-gamma pathway for time interval 2; and the bottom figure (c) shows peak total doses for the all-pathways for all times after 2126. Figure 6-2(a) shows that results do not vary between the inventory sets. This result occurs because the H-3 parent dominates the early total dose and its inventory is constant (at the maximum value, which is ET \#1's inventory) for all inventory sets.

Figure 6-2(b) shows total doses at much lower levels than those in Figure 6-2(a). The I-129 inventory set dominates followed by the Tc-99 inventory set, while changes in other parents' inventories do not increase total doses above those from the base case. If the maximum inventory set is applied, results only increase for Option 4 and ET \#1. For those two options the most important parent was I-129. However, Tc-99 was very important and when inventories for both I-129 and Tc-99 were increased to their maxima, the total doses exceeded those when only I-129 
was at it maximum inventory. During this second time interval, Options 2 and 3 results are better (lower total doses) than those for Option 1.

Figure 6-2(c) shows total doses at much higher levels than those in Figure 6-2(a), but those total doses are evaluated relative to much higher performance objectives ( $25 \mathrm{mrem} / \mathrm{yr}$ vs. $4 \mathrm{mrem} / \mathrm{yr})$ thus their impacts are much less. The Np-237 inventory set dominates for most options, although the Tc-99 inventory set is slightly more important than the other inventory sets for Option 1.

Option 4 always has the greatest doses, followed by ET \#1. Option 1 (for both its local 100-m buffer without plume interaction and its E-Area 100-m buffer with plume interaction) always has the smallest doses, while Options 2 and 3 fall in between Option 1 and ET \#1.

Results for the maximum inventory set are shown in Figure 6-1 alongside those based on ET \#1 inventories. Results for the maximum inventory set differ little from results from the base case inventory set - Option 4 consistently produces the highest doses, followed by ET \#1. Option 1 produces the lowest doses, while Options 2 and 3 are intermediate and are about equal to each other. 


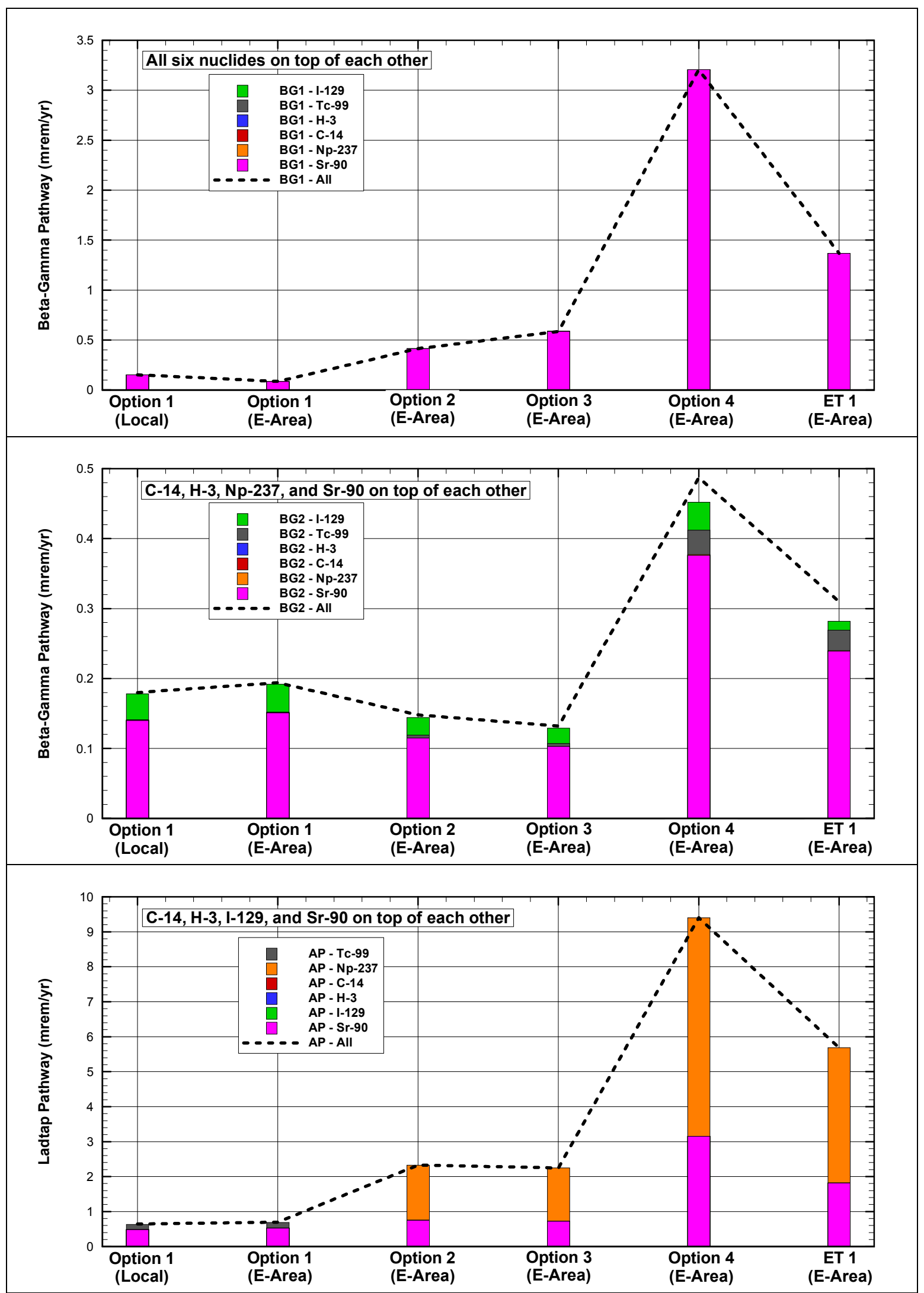

Figure 6-2 Peak doses for sensitivity inventory sets: a) BG1, b) BG2, and c) AP. 


\subsection{Qualitative Considerations}

Qualitative factors consist of aspects for each option that are important but that were not directly captured in the quantitative analyses. These factors are summarized in Table 6-4 without any consideration of their level of importance. They are a direct result of engineering judgments. Beneficial aspects ("pros") apply to Option 1 which provides increased capacity because it was never considered as disposal territory within the PA (2008). Option 1 also does not require excavation because waste would be disposed on the existing ground surface.

Detrimental aspects ("cons") apply to all the options. Options 2, 3, and 4 are detrimental in that ST capacity would be forfeited for new ET capacity. Options 1 and 4 are detrimental in that they would require more cap design and implementation than currently exists. Option 1 would require a more complicated Special Analysis due to existing concrete pads that were not considered in the current analysis and it might require DOE-HQ approval. The Special Analysis would require other decisions discussed below before the conceptual model could be finalized and the analysis started. Option 1 also has short-term and long-term regulatory issues because it is near existing RCRA caps that would require the following actions:

Short-term (before construction and/or operation)

- Decide if regulatory approval is needed due to MWMF and LLRWDF caps.

- Evaluate impact of ET \#3 runoff on north MWMF sediment basin.

- Integrate or separate (as needed) MWMF, LLRWDF and ET \#3 drainage systems.

- Evaluate width and height restrictions to avoid interference with MWMF and LLRWDF side slopes.

- Decide if a separate local $100-\mathrm{m}$ boundary is required or if merging with the current EArea boundary is acceptable.

\section{Long-term}

- Evaluate crane access for dynamic compaction.

- Evaluate minimum distance to avoid structural damage (vibrations) to existing caps and drainage structures.

Table 6-4 Qualitative factors.

\begin{tabular}{|l|c|c|c|c|}
\hline \multicolumn{1}{|c|}{ PROS: } & Option 1 & Option 2 & Option 3 & Option 4 \\
\hline \hline Increased capacity & $\checkmark$ & & & \\
\hline No excavation required & $\checkmark$ & & & \\
\hline
\end{tabular}

\begin{tabular}{|l|c|c|c|c|}
\hline \multicolumn{1}{|c|}{ coNS: } & Option 1 & Option 2 & Option 3 & Option 4 \\
\hline \hline Decreased ST capacity & & $\checkmark$ & $\checkmark$ & $\checkmark$ \\
\hline Increased cap design/implementation required & $\checkmark$ & & & $\checkmark$ \\
\hline $\begin{array}{l}\text { Option 1 Risk Factors: } \\
\text { Special Analysis complications (short-term cost) } \\
\begin{array}{l}\text { Regulatory risks with construction/operation } \\
\text { (short-term schedule and cost) } \\
\text { Regulatory risks with closure (long-term schedule and cost) }\end{array}\end{array}$ & $\checkmark$ & & & \\
\hline
\end{tabular}

\subsection{Summary}

Each option has a unique set of beneficial and detrimental aspects from both the quantitative and qualitative standpoints. Both types of aspects are presented as lists for each option below in the form of pros and cons. Conclusions from these lists are provided in the executive summary. 


\begin{tabular}{|c|c|}
\hline PROS & CONS \\
\hline \multicolumn{2}{|c|}{ 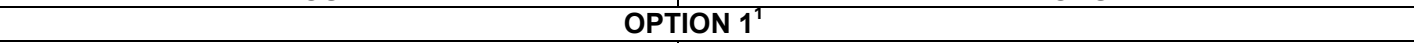 } \\
\hline - $\quad$ Increased capacity & - Increased cap design/implementation \\
\hline - $\quad$ No excavation required & - $\quad$ Special Analysis complications \\
\hline - $\quad$ On average best quasi-limits & - $\quad$ Regulatory risks with construction/operation \\
\hline - $\quad$ Averaged lowest doses for inventory sets & $\begin{array}{ll}\quad \text { Regulatory risks with closure } \\
\end{array}$ \\
\hline \multicolumn{2}{|c|}{ OPTION $2^{1,2}$} \\
\hline - $\quad$ Typically higher quasi-limits than Option 4 & - $\quad$ Typically lower quasi-limits than Option 1 \\
\hline - $\quad$ Typically better performance than Option 4 & - $\quad$ Typically worse performance than Option 1 \\
\hline & - $\quad$ Decreased ST capacity \\
\hline \multicolumn{2}{|c|}{ OPTION $3^{1,2}$} \\
\hline - $\quad$ Typically higher quasi-limits than Option 4 & - $\quad$ Typically lower quasi-limits than Option 1 \\
\hline - $\quad$ Typically better performance than Option 4 & - $\quad$ Typically worse performance than Option 1 \\
\hline & - $\quad$ Decreased ST capacity \\
\hline \multicolumn{2}{|c|}{ OPTION 4} \\
\hline & - $\quad$ Decreased ST capacity \\
\hline & - Increased cap design/implementation \\
\hline & - $\quad$ Lowest quasi-limits (except for C-14) \\
\hline & - $\quad$ Highest doses for inventory sets \\
\hline
\end{tabular}

${ }^{1}$ If the anticipated inventory is outside historical trends, an optimum choice among Options 1, 2, and 3 may be possible ${ }^{2}$ Options 2 and 3 are equally suitable

\subsection{References}

Collard, L. B. and L. L. Hamm, 2011. "Guidance for Slit Trench Disposals Based on Lessons Learned to Help Compensate for Non-uniformity Aspects," SRNL-STI-2011-00403, Rev. 0, Savannah River Nuclear Solutions, Savannah River Site, Aiken, SC 29808, July, 2011.

Hiergesell, 2011. "GSA Ground Surface and Water Table Elevation Data Transfer by e-mail." Internal SRNL email of elevation data on November 21, 2011.

ICRP 1995. "Age-dependent Doses to the Members of the Public from Intake of Radionuclides Part 5 Compilation of Ingestion and Inhalation Coefficients", ICRP Publication 72, Annals of the ICRP 26 (1).

Jordan, 2011. "E-Area Files by e-mail." Internal SRNL email of aquifer modeling files on November 7, 2011.

Kaplan, D. I., 2010. “Geochemical Data Package For Performance Assessment Calculations Related To The Savannah River Site," SRNL-STI-2009-00473, Savannah River Nuclear Solutions, Savannah River Site, Aiken, SC 29808, March 15, 2010.

Millings, M. and L. Bagwell, 2011. "Upper Vadose Zone and Tan Clay Confining Zone Recommendations: Potential ET 3 Locations," SRNL-L3200-2011-00009, Savannah River Nuclear Solutions, Savannah River Site, Aiken, SC 29808, December, 2011.

PA, 2008. "E-Area Low Level Waste Facility DOE 435.1 Performance Assessment," WSRC-STI-2007-00306, Revision 0, Washington Savannah River Company, LLC, Aiken, SC, March 2008.

Phifer, M. A., 2011. "Engineered Trench \#3 Location Options Evaluation: Intact and Subsided Infiltration Estimates," SRNL-L3200-2011-00009, Savannah River Nuclear Solutions, Savannah River Site, Aiken, SC 29808, December, 2011.

Phifer, M. A., M. R. Millings, and G. P. Flach, 2006. "Hydraulic Property Data Package for the E-Area and Z-Area Soils, Cementitious Materials and Waste Zones," WSRC-STI-200600198, Rev.0, Washington Savannah River Company, September 2006. 
Roberts, K. A. and D. I. Kaplan 2008. "Carbon-14 Geochemistry at Savannah River Site," SRNLSTI-2008-00445. Savannah River National Laboratory, Aiken, SC 29808, December 9, 2008.

Swingle, R. F., R. A. Hiergesell, G. K. Humphries, M. R. Millings, D. F. Sink, 2012. "FY 2011 Annual Review E-Area Low-Level Waste Facility Performance Assessment and SRS Composite Analysis," SRNS-STI-2012-00014, Revision 0, January 2012. 


\section{Appendix A}

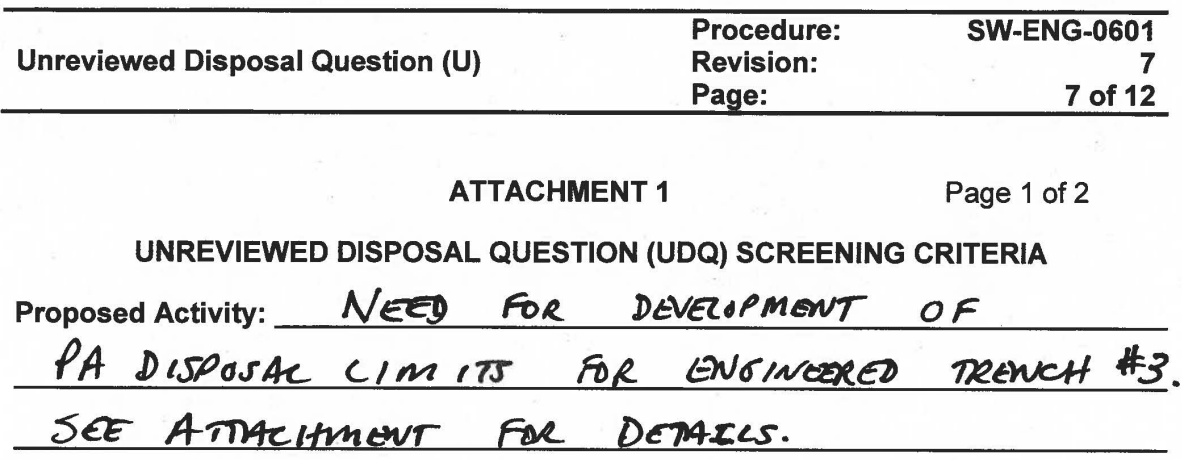

REVIEW the following questions against the Proposed Activity:
1. Yes $X$
No
N/A
Does the proposed disposal activity or new information involve a change to the disposal facility from what has been previously described or analyzed in the most recent Performance Assessment, Composite Analysis, approved Special Analyses, or approved UDQ Evaluations?

2. Yes $\square$ No $\square$ N/A

Does the proposed disposal activity or new information involve a change to the disposal process or procedures from what has been previously described or analyzed in the most recent Performance Assessment, Composite Analysis, approved Special Analyses, or approved UDQ Evaluations?

3.

$$
\text { No } \bigotimes \text { N/A }
$$

Does the proposed disposal activity or new information involve a change to the radionuclide disposal limits from what has been previously described or analyzed in the most recent Performance Assessment, Composite Analysis, approved Special Analyses, or approved UDQ Evaluations?

4. Yes $\square$ No $\square$ N/A

Does the proposed disposal activity or new information involve a change to the Waste Acceptance Criteria from what has been previously described or analyzed in the most recent Performance Assessment, Composite Analysis, approved Special Analyses, or approved UDQ Evaluations?

\section{Yes $\square$ No $\square$ N/A}

Does the proposed disposal activity or new information involve a change to what has been previously described or analyzed in the PA / Composite Analysis Inputs and Assumptions (I\&A) Database? 


\begin{tabular}{lr} 
Procedure: & SW-ENG-0601 \\
Revision: & 7 \\
Page: & 8 of 12 \\
\hline
\end{tabular}

ATTACHMENT 1

Page 2 of 2

\section{UNREVIEWED DISPOSAL QUESTION (UDQ) SCREENING CRITERIA}

\section{Yes $\square$ No $X \quad$ N/A}

Does the proposed disposal activity or new information involve a change to the facility closure design or criteria from what has been previously described or analyzed in the most recent Performance Assessment, Composite Analysis, approved Special Analyses, approved UDQ Evaluations or associated Closure Plan?

\section{Yes $\square$ No $\square$ N/A}

Does the proposed disposal activity or new information involve a test or experiment not described or analyzed in the most recent Performance Assessment, Composite Analysis, approved Special Analyses, approved UDQ Evaluations or associated Closure Plan?

\section{Yes $\square \quad$ No $\bigotimes \quad$ N/A}

Does the proposed disposal activity or new information involve any analytical errors, omissions or deficiencies in the most recent Performance Assessment, Composite Analysis, approved Special Analyses, approved UDQ Evaluations or associated Closure Plan?

If all questions above are answered "No" or "N/A" (defined by a $~$ in the box provided), then implement Proposed Activity in Performance Assessment space. If any of the questions above answered "Yes" (defined by a $\nu$ in the box provided), then forward to SRNL for development of an UDQ Evaluation or Special Analysis.

Provide Explanation I Justification for all "Yes" answers:

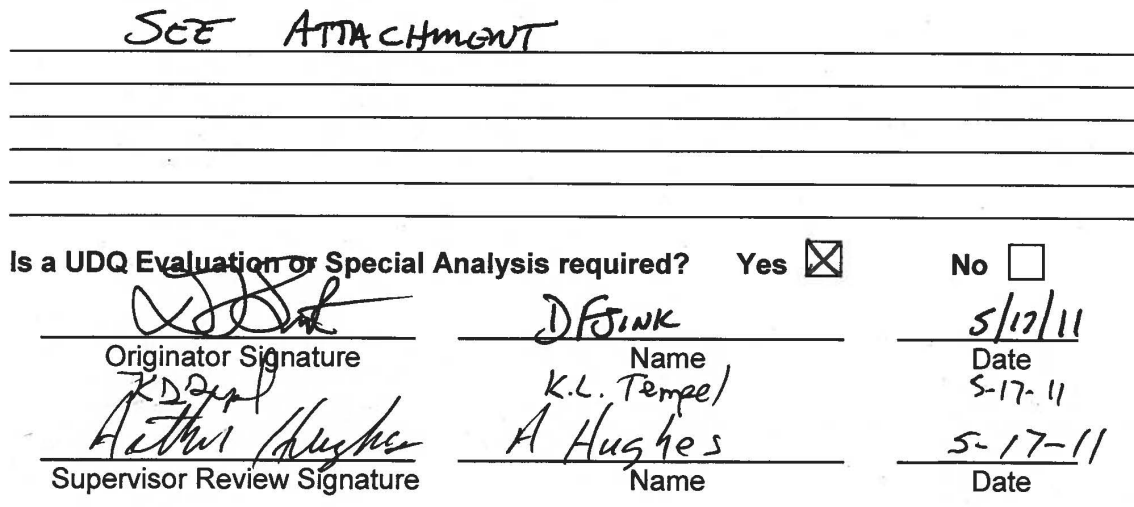


Engineered Trench \#2 will close in Fy14 based on Low Level Waste disposed to date and waste forecasts from the generators. This facility design provides a unique and cost effective disposal option for containerized Low Level Waste, using defined Performance Assessment (PA) disposal limits. Thus, a new facility should be developed for future Low Level Waste trench disposal.

Solid Waste will need to locate the next Engineered Trench (ET\# 3) in E Area. There are four disposal options under consideration (see attachment):

Option 1 - Placement of waste at grade / above grade on existing on TRU Pads 7 through 13 Area and mounding clean soil over disposed waste packages. A sump will be added to collect water runoff for sampling prior to release.

Option 2 - Construct a new Engineered Trench near the Used Equipment Storage Area, using the similar design features of Engineered Trench \#2.

Option 3 - Construct a new Engineered Trench near the 643-26E Naval Reactor Component Disposal Area, using the similar design features of Engineered Trench \#2.

Option 4 - Construct a new Engineered Trench near the TRU Pad \# 26, using similar design features of Engineered Trench \#2.

Solid Waste requests SRNL to develop an assessment report that reviews each disposal option and determines which option provides the best PA disposal limits for LLW. Other location options can be considered by Solid Waste if proposed by SRNL. Once this report is complete and approved by Solid Waste, a Special Analysis (SA) will need to be developed and approved for the preferred option. This SA will define the new PA disposal limits before any design and construction work can begin.

Solid Waste requests such a report and Special Analysis be issued and approved (including DOE approval) in Fy12. 


\section{Option 1}

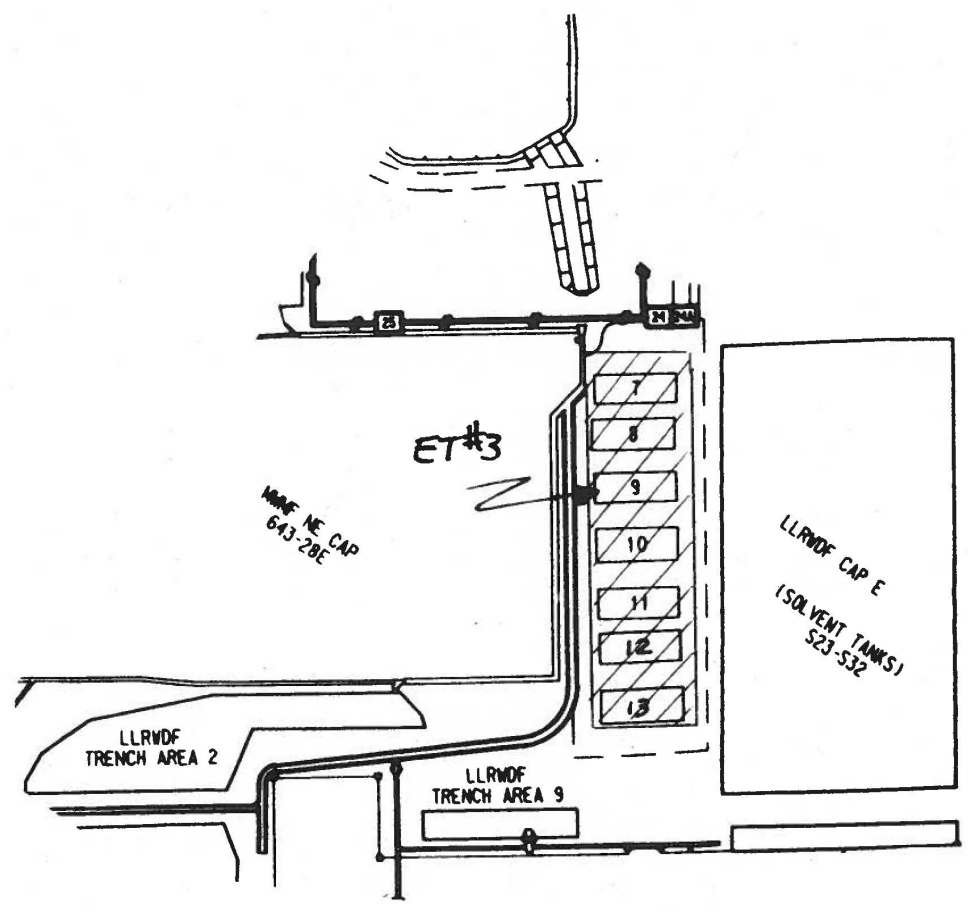




\section{Option 2}

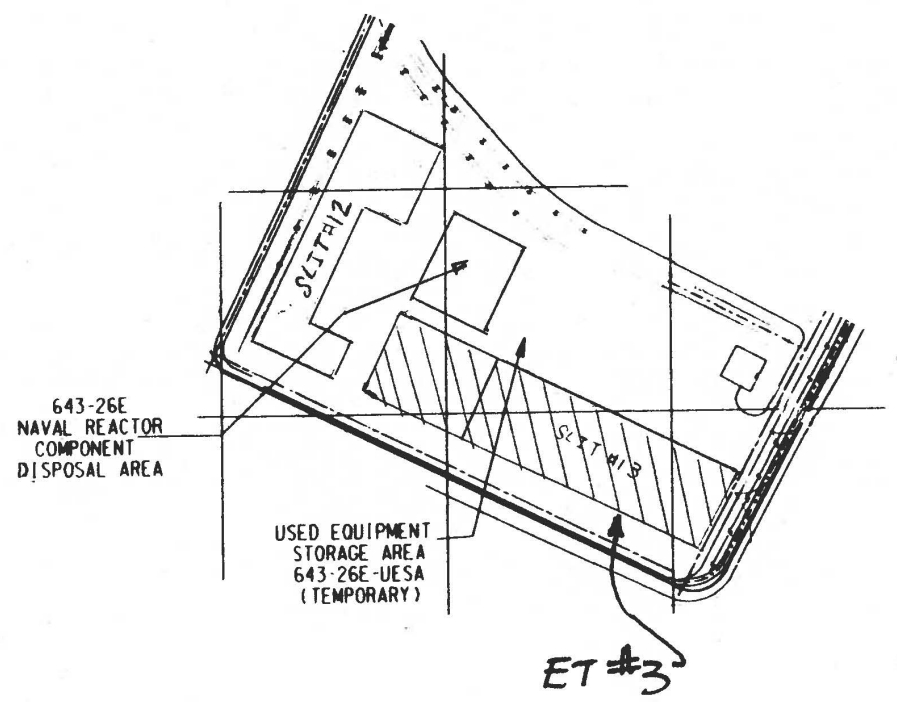




\section{Option 3}

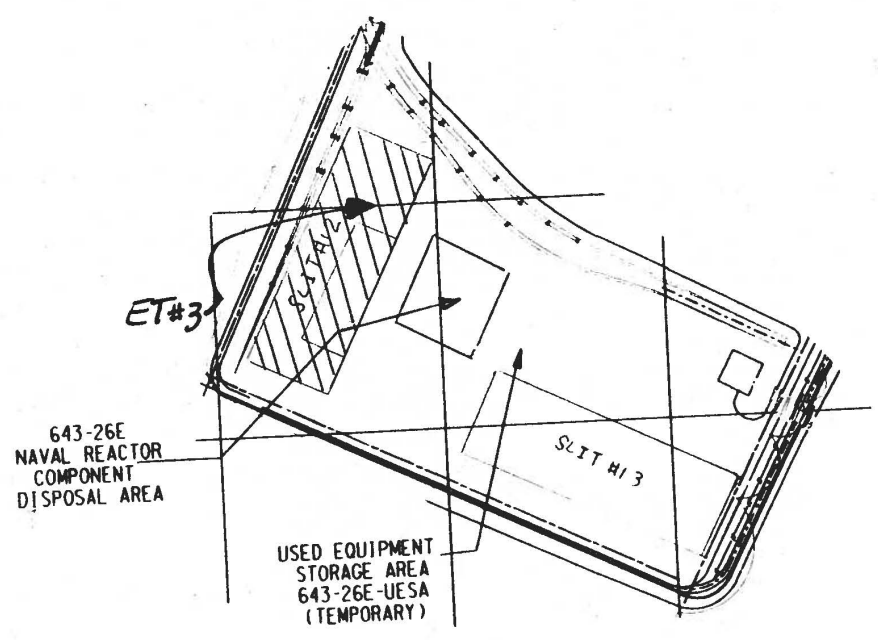




\section{Option 4}

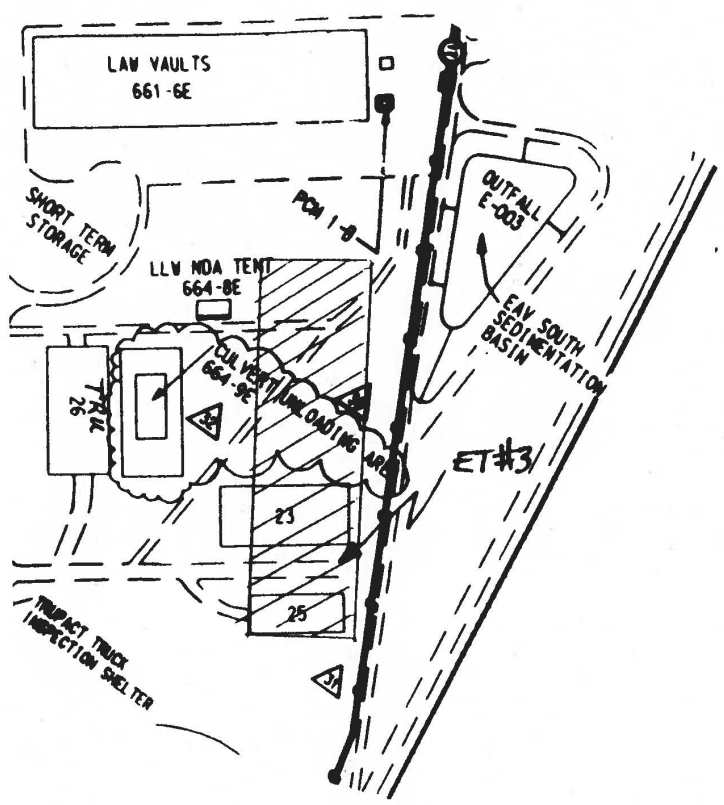


This page is left blank intentionally 


\section{Distribution:}

R. S. Aylward, 773-42A

L. A. Bagwell, 773-42A

H. H. Burns, 773-41A

B. T. Butcher, 773-43A

L. B. Collard, 773-43A

D. A. Crowley, 773-43A

G. P. Flach, 773-42A

F. L. Fox, 704-59E

J. C. Gilmour, 704-59E

J. C. Griffin, 773-A

L. L. Hamm,703-41A

M. A. Heitkamp, 999-W

S. J. Hensel, 703-41A

R. A. Hiergesell, 773-43A

A. R. Hughes, 704-56E

G. K. Humphries, 705-3C

J. M. Jordan, 703-41A

M. A. Kokovich, 704-60E

K. M. Kostelnik, 705-3C

D. I. Kaplan, 773-43A

D. Li, 773-43A

M. G. Looper, 704-36E

J. J. Mayer, 773-42A

L. C. Martin, 704-34E

M. R. Millings, 773-42A

T. O. Oliver, $773-42 \mathrm{~A}$

M. A. Phifer, 773-42A

S. R. Reed, 704-56E

K. A. Roberts, 773-43A

R. R. Seitz, 773-43A

D. F. Sink, 704-56E

F. G. Smith, 703-41A

R. F. Swingle, 773-43A

G. A. Taylor, 773-43A

K. L. Tempel, 704-56E

C. Wilson (1 file copy \& 1 electronic copy), 773-43A - Rm. 213 